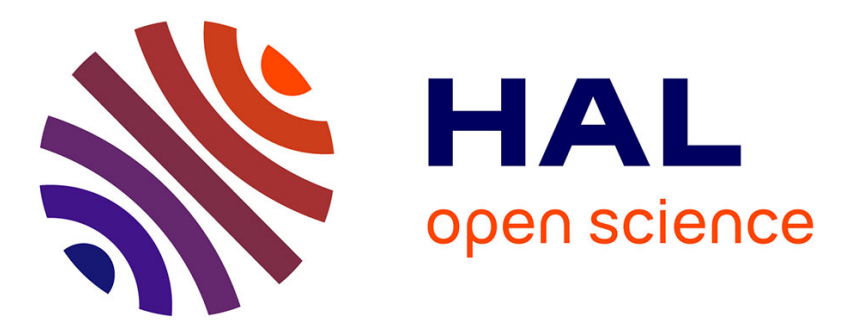

\title{
Late pleistocene variability of the carbon isotopic composition of organic matyer in the eastern mediterranean: monitor of changes in carbon sources and atmospheric $\mathrm{CO} \_2_{2}$ concentrations
}

\author{
M. R Fontugne, S. E Calvert
}

\section{To cite this version:}

M. R Fontugne, S. E Calvert. Late pleistocene variability of the carbon isotopic composition of organic matyer in the eastern mediterranean: monitor of changes in carbon sources and atmospheric CO_2 concentrations. Paleoceanography, 1992, 7 (1), pp.1-20. 10.1029/91PA02674 . hal-03544140

\author{
HAL Id: hal-03544140 \\ https://hal.science/hal-03544140
}

Submitted on 26 Jan 2022

HAL is a multi-disciplinary open access archive for the deposit and dissemination of scientific research documents, whether they are published or not. The documents may come from teaching and research institutions in France or abroad, or from public or private research centers.
L'archive ouverte pluridisciplinaire HAL, est destinée au dépôt et à la diffusion de documents scientifiques de niveau recherche, publiés ou non, émanant des établissements d'enseignement et de recherche français ou étrangers, des laboratoires publics ou privés. 


\section{LATE PLEISTOCENE VARIABILITY OF THE CARBON ISOTOPIC COMPOSITION OF ORGANIC MATTER IN THE EASTERN MEDITERRANEAN: MONITOR OF CHANGES IN CARBON SOURCES AND ATMOSPHERIC $\mathrm{CO}_{2}$ CONCENTRATIONS}

\author{
M. R. Fontugne \\ Centre des Faibles Radioactivités, Laboratoire Mixte \\ CNRS-CEA, Gif-sur-Yvette, France
}

\author{
S. E. Calvert \\ Department of Oceanography, University of British \\ Columbia, Vancouver, British Columbia, Canada
}

are probably produced by changes in the isotopic composition and the concentration of dissolved $\mathrm{CO}_{2}$. First, freshwater flooding during the formation of the sapropels caused the isotopic composition of the dissolved inorganic carbon in the surface waters of the Mediterranean to become lighter because of the ${ }^{13} \mathrm{C}$ deficiency in fresh waters. Hence photosynthesis would have produced isotopically lighter organic material. Second, changes in atmospheric $\mathrm{pCO}_{2}$ between glacial and interglacial periods, as shown by the Vostok ice core, caused marked changes in the concentration of free dissolved $\mathrm{CO}_{2}$ in the mixed layer; lower values during glacial maxima caused a smaller fractionation of the carbon isotopes by phytoplankton, whereas levels were less limiting during the interglacials. Concentrations of dissolved $\mathrm{CO}_{2}$ could also have been much higher during the deposition of the sapiopels because of the supply of regenerated $\mathrm{CO}_{2}$ to the mixed layer by upwelling, and this could have further lightened the $\delta^{13} C_{\text {organic }}$ values in the sapropels themselves. Carbon isotope records may provide an alternative method for estimating atmospheric $\mathrm{pCO}_{2}$ levels over longer time periods than can be obtained from ice cores.

\section{INTRODUCTION}

The occurrence and significance of organic-rich sediments (sapropels) in the Holocene and upper Pleistocene section of the eastern Mediterranean [Kullenberg, 1952] have elicited considerable interest [Olausson, 1961; Ryan, 1972; McCoy, 1974; Ryan and Cita, 1977; Cita et al., 1977; Thunell et al., 1977; Vergnaud-Grazzini et al., 1977; Williams

Paper number 91PA02674. 
Fontugne and Calvert: Mediterranean $\delta^{13} \mathrm{C}_{\text {organic }}$ Variations

et al., 1978; Williams and Thunell, 1979; Cita and Grignani, 1982; Rossignol-Strick et al., 1982; Thunell et al., 1983; Calvert, 1983; RossignolStrick, 1985]. Such sediments occur intercalated in the nano-fossil and foraminiferal marl oozes that constitute the normal sedimentary facies of this basin. They have been recovered either by piston coring or by drilling; 12 such horizons occur in the late Quaternary section (sapropels S1-S12 of McCoy [1974] and Cita et al. [1977]), whereas an even larger number occur in older strata [Kidd et al., 1978]. They evidently formed mainly during the late stages of deglaciation, or during "warming trends" [Ryan, 1972]. The two prevailing explanations for their origin are (1) increased organic carbon preservation under bottom-water anoxia when deepwater renewal was restricted by the presence of low-salinity surface waters derived from increased run-off, either from the Black Sea [Olausson, 1961; Ryan, 1972; Thunell et al., 1977; VergnaudGrazzini et al., 1977; Thunell and Williams, 1982; Jenkins and Williams, 1984] or from the Nile [Rossignol-Strick, 1983, 1985; Rossignol-Strick et al., 1982], and (2) a higher settling flux of organic matter caused by increased primary production when the circulation of the eastern basin was reversed as a consequence of the increased run-off [Berger, 1976; Calvert, 1983; Sutherland et al., 1984].

Whatever mechanism might be responsible for their formation, it is clear that the sapropels contain valuable records of changing oceanographic conditions in the eastern basin of the Mediterranean throughout the late Pleistocene. Knowledge of their geochemistry and stable isotopic characteristics should enable us to obtain information on, among other things, the history of changing hydrographic conditions, circulation, carbon sources, and burial in the basin. Of particular interest here, it should be possible to identify the sources of organic matter in the sapropels from its bulk chemical composition, its molecular characteristics, and its stable isotopic composition. This information will be relevant to the question of the intensity of primary planktonic production, and hence the flux of organic carbon to the seafloor, during sapropel-forming events, the importance of terrestrial versus marine sources of organic materials, and whether different marine planktonic assemblages inhabited the photic zone during the deposition of the sapropel and the marl oozes. Finally, this information will be relevant to the contentious issue of the origin of organic-rich facies in the modern ocean and in the geological record.

Available information on the ultimate sources of organic matter in the sapropels is highly equivocal. On the basis of the abundance of fragments of higher plants, including pollen, high organic $\mathrm{C} / \mathrm{N}$ ratios, the distribution of $n$-alkanes, the composition of humic substances and the results of pyrolysis analysis, Deroo et al. [1978] and Sigl et al. [1978] contended that the organic matter in Pleistocene sapropels recovered by the Deep Sea Drilling Project is largely terrestrial. This would be consistent with the notion that increased terrestrial input was a factor in the formation of these deposits [Rossignol-Strick et al., 1982; Shaw and Evans, 1984]. In contrast, Rossignol-Strick et al. [1982], Shaw and Evans [1984] and Smith et al. [1986] found that the lipid fraction of the organic matter in $S 1$ is predominantly of marine origin, with clearly recognizable inputs from dinoflagellates and coccolithophorids, although a significant terrigenous component is also present. They also pointed out that the marl oozes contain an even higher relative abundance of terrestrial organic material compared with the sapropels. Ten Haven et al. [1987] also identified a wide range of higher plant fragments and pollen in $\mathbf{S} 1$ in a profile of cores from the Nile region to the central basin of the eastern Mediterranean but nevertheless concluded that the bulk organic matter comprises a mixture of marine, terrestrial, and bacterial components, with the importance of terrestrial material increasing away from the Nile towards the deep basin.

The carbon isotopic composition of the organic matter in S1 has been interpreted as having a predominantly marine signature [Sutherland et al., 1984; Ten Haven et al., 1987] with $\delta^{13} \mathrm{C}$ values ranging from -18.5 to $-22.6 \%$. Ten Haven et al. [1987] suggested that the lighter values found in cores from the deep central basin compared with those from the shallow-water area close to the Nile indicate a larger terrestrial component away from the coast, consistent with the organic geochemical evidence. Sutherland et al. [1984] found that the $\delta^{13} \mathrm{C}$ values vary from -18.5 to $-21.6 \%$ in $S 1$ at a single site far removed from the influence of the Nile. As we shall discuss below, inadequate knowledge of the carbon isotopic composition of the organic end-members in the Mediterranean makes it extremely difficult to determine precisely the terrestrial fraction of the organic matter present in the sapropels from this meagre information.

We have attempted to examine this problem by carrying out a more detailed study of the carbon isotopic composition of the organic matter in a sediment sequence from the easternmost Mediterranean containing several sapropel horizons. The original aim of the study was to determine the proportions of marine and terrestrial organic matter in the sapropels and associated sediments, but the results have required a more extensive investigation of the multiple causes of isotopic variability in marine sediment records.

\section{MATERIALS AND METHODS}

Core MD $84641\left(33^{\circ} 02^{\prime} \mathrm{N}, 32^{\circ} 38^{\prime} \mathrm{E} ; 1375 \mathrm{~m}\right)$ was collected during the NOE cruise of the R/V Marion Dufresne in August 1984. It was stored at $4^{\circ} \mathrm{C}$ and 
sampled two weeks after collection. Separate samples were taken for foraminiferal isotopic and for chemical and mineralogical analyses. Sampling was at $10 \mathrm{~cm}$ intervals in the marl ooze sections of the core and at $2 \mathrm{~cm}$ intervals through the sapropels. Standard methods were used for the separation and cleaning of samples of Globigerinoides ruber; the isotopic composition of these samples was determined using either a VG 602D or a Finnegan 251 mass spectrometer at Gif-sur-Yvette. The results are reported in the standard $\delta$ notation relative to the Pee Dee Belemnite (PDB) standard. Organic carbon determinations at Gif-sur-Yvette were made by combustion, followed by coulometric determination of the evolved $\mathrm{CO}_{2}$, of subsamples that were soaked in $10 \% \mathrm{HCl}$ ovemight and dried to constant weight at $80^{\circ} \mathrm{C}$. Absolute precision was better than $0.1 \%$. Samples for chemical and isotopic analyses of the organic fraction at UBC were dried at $60^{\circ} \mathrm{C}$ to constant weight and then ground to fine powders in a disc mill. Subsamples were used for total carbon and nitrogen determination by combustion/gas chromatography; the precisions determined on replicate subsamples were $\pm 1.25 \%$ and $\pm 3.5 \%$, respectively. Carbonate carbon was determined by acid digestion followed by coulometric determination of the evolved $\mathrm{CO}_{2}$; precision was $\pm 2 \%$. Organic carbon values were derived by the difference between total and carbonate carbon values, the combined precision being $\pm 2.35 \%$. Differences between the two organic carbon data sets were generally less than $\pm 5 \%$. The carbon isotopic determinations in the entire core were carried out on decarbonated subsamples using a VG PRISM mass spectrometer with an on-line CHN analyzer as the gas preparation device at UBC. The results are also reported in the $\delta$ notation relative to PDB, and the precision of the measurements was $\pm 0.05 \%$. A smaller number of samples was also analyzed at Gifsur-Yvette by procedures described by Fontugne [1983], which involved off-line combustion of decarbonated samples in a stream of oxygen and the cleaning and trapping of the $\mathrm{CO}_{2}$ cryogenically. Determinations were made using a VG 602C mass spectrometer, and the precision was $\pm 0.1 \%$. The absolute differences between the two data sets averaged $0.66 \pm 0.59 \%$, with no systematic bias.

\section{RESULTS}

Core MD 84641 consists of 11.61 metres of pale cream to yellowish brown nanofossil/foraminiferal marl ooze with nine olive green sapropels varying in thickness from 6 to $22 \mathrm{~cm}$. Figure $1 \mathrm{a}$ and Table 1 show that the peak organic carbon contents of the sapropels range from 2 to $4.5 \%$ by weight. Four of the sapropels (those at 328-341, 374-393, 458479.5 , and $578-596 \mathrm{~cm}$ ) contain grey mud layers with lower organic carbon contents, producing two maxima in organic carbon content at each level. The

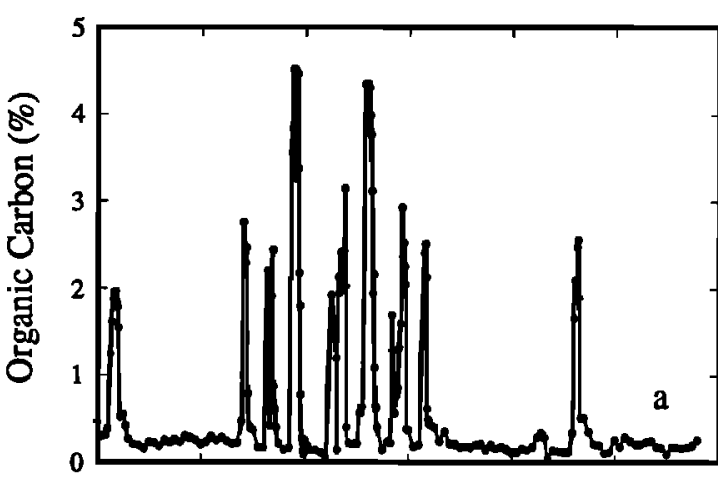

Fig. 1a. Distribution of organic carbon with depth in core MD 84641.

marl oozes have organic carbon contents ranging from 0.1 to $0.3 \%$, with no systematic trends in this lithology down the core.

The $\mathrm{C}_{\text {organic }} \mathrm{N}$ ratio varies in a systematic manner throughout the core (Figure 1b). It is higher in the sapropels (16.92 \pm 1.13$)$, defined as those horizons with $>1 \%$ organic $\mathrm{C}$, compared with the marl oozes $(12.34 \pm 4.10)$. This difference is significant at the $<1 \%$ level (two-sided $t$-test).

The chronostratigraphy of the core is based on the

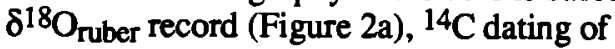
planktonic foraminifera in the upper $135 \mathrm{~cm}$ of the core and palaeomagnetic reversal stratigraphy. The radiocarbon data show that the uppermost sapropel has age ranges of 6500 and approximately 9000 years B.P. [Fontugne et al, 1989a, b] and is therefore S1 [McCoy, 1974]. The $\delta^{18} \mathrm{O}_{\text {ruber record }}$ shows a range of -2.3 to $+3.2 \%$, consistent with other foraminiferal records from the Mediterranean that all show a much larger glacial/interglacial range than that in the Atlantic [Vergnaud-Grazzini et al., 1977]. Correlation with the Specmap stack [Martinson et al., 1987] shows that the record in this

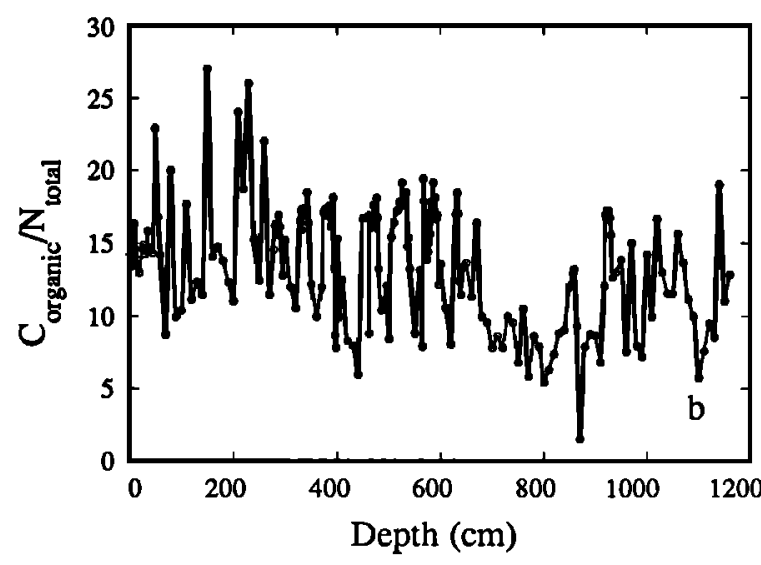

Fig. 1b. Distribution of $\mathrm{C}_{\text {organic }} / \mathrm{N}$ ratios with depth in core MD 84641 . 
TABLE 1. Compositional and isolopic data on core MD 84641

\begin{tabular}{|c|c|c|c|c|c|c|c|c|}
\hline $\begin{array}{c}\text { Sample } \\
\text { Depth (cm) } \\
\text { Chemistry }\end{array}$ & $\begin{array}{l}\text { Intepolated } \\
\text { Age, years }\end{array}$ & $\begin{array}{l}\text { Organic C } \\
\text { percent }\end{array}$ & $\begin{array}{l}\text { Total N } \\
\text { percent }\end{array}$ & $\begin{array}{c}\delta^{13} C_{\text {organic }} \\
(\% \circ)\end{array}$ & $\begin{array}{c}\text { Sample } \\
\text { Depth (cm) } \\
\text { Forams }\end{array}$ & $\begin{array}{l}\text { Interpolated } \\
\text { Age, years }\end{array}$ & $\begin{array}{c}\delta^{18} \mathrm{O} \\
G . \text { nuber }(\%) \text { ) }\end{array}$ & $\begin{array}{c}\delta^{13} \mathrm{C} \\
G . \text { ruber }(\%)\end{array}$ \\
\hline 0 & 0 & 0.47 & 0.033 & -19.90 & 1 & 216 & 0.84 & 1.84 \\
\hline 5 & 1081 & 0.31 & 0.023 & -18.81 & 3 & 649 & 0.79 & 1.95 \\
\hline 10 & 2162 & 0.31 & 0.019 & -19.99 & 10 & 2162 & 0.04 & 1.38 \\
\hline 15 & 3243 & 0.32 & 0.023 & -19.33 & 13 & 2811 & 0.05 & 1.67 \\
\hline 20 & 4324 & 0.39 & 0.030 & -20.13 & 20 & 4324 & -0.57 & 1.25 \\
\hline 25 & 5405 & 1.24 & 0.085 & -20.43 & 22 & 4757 & 0.04 & 0.93 \\
\hline 27 & 5838 & 1.61 & 0.108 & -20.03 & 24 & 5189 & -0.31 & 1.18 \\
\hline 30 & 6486 & 1.87 & 0.131 & -21.01 & 26 & 5622 & -0.46 & 1.00 \\
\hline 33 & 7135 & 1.93 & 0.133 & -21.36 & 28 & 6054 & -0.44 & 0.84 \\
\hline 35 & 7568 & 1.96 & 0.124 & -21.19 & 29 & 6270 & -0.56 & 0.83 \\
\hline 37 & 8000 & 1.83 & 0.124 & -21.16 & 32 & 6919 & -0.80 & 0.94 \\
\hline 38 & 4389 & 1.78 & 0.121 & -21.19 & 33 & 7135 & -0.64 & 0.89 \\
\hline 40 & 8777 & 1.54 & 0.105 & -20.57 & 36 & 7784 & -0.99 & 1.01 \\
\hline 45 & 10073 & 0.53 & 0.037 & -18.38 & 37 & 8000 & -1.37 & 1.16 \\
\hline 50 & 11368 & 0.55 & 0.024 & -17.56 & 39 & 8518 & -1.28 & 1.34 \\
\hline 55 & 12663 & 0.42 & 0.025 & -17.74 & 40 & 8777 & -0.91 & 1.02 \\
\hline 60 & 13959 & 0.27 & 0.019 & -17.79 & 42 & 9295 & -0.15 & 1.20 \\
\hline 70 & 16549 & 0.21 & 0.024 & -18.91 & 43 & 9554 & -0.04 & 0.83 \\
\hline 80 & 18619 & 0.20 & 0.010 & -18.41 & 45 & 10073 & -0.08 & 1.04 \\
\hline 90 & 20689 & 0.16 & 0.016 & -18.57 & 46 & 10332 & 0.16 & 1.16 \\
\hline 100 & 22581 & 0.24 & 0.023 & -17.51 & 48 & 10850 & 0.27 & 1.06 \\
\hline 110 & 24474 & 0.23 & 0.013 & -16.89 & 50 & 11368 & 1.05 & 0.78 \\
\hline 120 & 28900 & 0.19 & 0.017 & -17.09 & 57 & 13181 & 1.24 & 1.18 \\
\hline 130 & 33326 & 0.26 & 0.021 & -17.83 & 60 & 13959 & 1.37 & 1.30 \\
\hline 140 & 36140 & 0.23 & 0.020 & -17.66 & 65 & 15254 & 0.92 & 1.14 \\
\hline 150 & 38954 & 0.27 & 0010 & -16.96 & 70 & 16549 & 2.47 & 1.17 \\
\hline 160 & 41768 & 0.24 & 0.017 & -17.25 & 75 & 17850 & 3.20 & 1.51 \\
\hline 170 & 44582 & 0.31 & 0021 & -17.35 & 85 & 19743 & 3.09 & 1.58 \\
\hline 180 & 47396 & 0.29 & 0.021 & -16.69 & 90 & 20689 & 3.01 & 1.57 \\
\hline 190 & 50210 & 0.26 & 0.021 & -17.12 & 95 & 21635 & 297 & 1.65 \\
\hline 200 & 53333 & 0.21 & 0.019 & -16.67 & 100 & 22581 & 2.61 & 1.48 \\
\hline 210 & 56455 & 0.24 & 0.010 & -17.30 & 105 & 23528 & 2.63 & 1.64 \\
\hline 220 & 59578 & 0.30 & 0.016 & -17.58 & 110 & 24474 & 2.66 & 1.49 \\
\hline 230 & 62700 & 026 & 0.010 & -16.95 & 115 & 25420 & 2.28 & 1.45 \\
\hline 240 & 65823 & 029 & 0.019 & -17.04 & 125 & 31919 & 2.75 & 1.50 \\
\hline 250 & 68945 & 0.25 & 0.020 & -1802 & 130 & 33326 & 2.47 & 1.13 \\
\hline 260 & 72068 & 0.22 & 0.010 & -18.60 & 135 & 34733 & 2.69 & 1.47 \\
\hline 270 & 75190 & 0.23 & 0.020 & -19.30 & 140 & 36140 & 2.27 & 1.16 \\
\hline 278 & 77689 & 0.48 & 0033 & -19.14 & 150 & 38954 & 2.54 & 111 \\
\hline 280 & 78313 & 2.76 & 0.170 & -19.92 & 160 & 41768 & 1.70 & 0.97 \\
\hline 283 & 79250 & 2.40 & 0.147 & -20.06 & 170 & 44582 & 1.61 & 1.47 \\
\hline 285 & 80117 & 2.29 & 0.147 & -19.79 & 180 & 47396 & 128 & 1.20 \\
\hline 287 & 80983 & 2.47 & 0.146 & -19.43 & 190 & 50210 & 1.24 & 1.24 \\
\hline 290 & 82283 & 0.79 & 0.049 & -1861 & 200 & 53333 & 1.52 & 1.38 \\
\hline 295 & 84450 & 0.41 & 0.032 & -17.96 & 210 & 56455 & 131 & 1.24 \\
\hline 300 & 86617 & 0.38 & 0.025 & -18.31 & 220 & 59578 & 1.23 & 1.48 \\
\hline 310 & 90950 & 0.18 & 0.015 & -19.71 & 230 & 62700 & 1.83 & 1.46 \\
\hline 320 & 92317 & 0.18 & 0.017 & -19.06 & 240 & 65823 & 1.90 & 1.61 \\
\hline 328 & 95142 & 2.20 & 0.133 & -21.34 & 250 & 68945 & 2.24 & 1.61 \\
\hline 330 & 95848 & 0.81 & 0.047 & -19.48 & 260 & 72068 & 2.20 & 1.78 \\
\hline 332 & 96555 & 0.43 & 0027 & -18.22 & 270 & 75190 & 0.94 & 1.51 \\
\hline 335 & 97614 & 1.91 & 0.110 & -21.24 & 280 & 78313 & 0.08 & 0.98 \\
\hline 338 & 98674 & 2.44 & 0.144 & -21.58 & 283 & 79250 & -0.69 & 1.11 \\
\hline 340 & 99380 & 0.87 & 0.050 & -19.28 & 285 & 80117 & -064 & 0.75 \\
\hline 342 & 101662 & 0.61 & 0.033 & -2017 & 287 & 80983 & -0.37 & 0.96 \\
\hline 345 & 105085 & 0.41 & 0.025 & -19.06 & 290 & 82283 & 0.83 & 1.35 \\
\hline 350 & 110790 & 0.22 & 0.018 & -19.22 & 300 & 86617 & 147 & 1.68 \\
\hline 360 & 114409 & 0.15 & 0.015 & -19.95 & 310 & 90950 & 162 & 1.28 \\
\hline 370 & 118029 & 0.18 & 0.015 & -1952 & 320 & 92317 & 065 & 1.14 \\
\hline 373 & 119115 & 3.56 & 0.208 & -2065 & 328 & 95142 & 0.02 & 0.81 \\
\hline $\begin{array}{l}375 \\
377\end{array}$ & $\begin{array}{l}119838 \\
120562\end{array}$ & $\begin{array}{l}3.84 \\
4.52\end{array}$ & $\begin{array}{l}0.223 \\
0.267\end{array}$ & $\begin{array}{l}-20.62 \\
-20.49\end{array}$ & $\begin{array}{l}330 \\
332\end{array}$ & $\begin{array}{l}95848 \\
96555\end{array}$ & $\begin{array}{l}0.40 \\
0.92\end{array}$ & $\begin{array}{l}0.95 \\
1.34\end{array}$ \\
\hline 380 & 121648 & 3.80 & 0.218 & -20.62 & 335 & 97614 & 0.02 & 1.11 \\
\hline 382 & 122372 & 3.27 & 0.191 & -20.69 & 338 & 98674 & 0.31 & 0.57 \\
\hline 384 & 123096 & 4.47 & 0.254 & -20.60 & 340 & 99380 & -1.12 & 0.72 \\
\hline 386 & 123820 & 3.38 & 0.201 & -20.50 & 342 & 101662 & 0.15 & 0.87 \\
\hline 388 & 125007 & 2.18 & 0.135 & -20.47 & 345 & 105085 & 0.49 & 1.04 \\
\hline
\end{tabular}


TABLE 1.(continued)

\begin{tabular}{|c|c|c|c|c|c|c|c|c|}
\hline $\begin{array}{c}\text { Sample } \\
\text { Depth (cm) } \\
\text { Chemistry }\end{array}$ & $\begin{array}{l}\text { Interpolated } \\
\text { Age, years }\end{array}$ & $\begin{array}{c}\text { Organic C } \\
\text { percent }\end{array}$ & $\begin{array}{l}\text { Total N } \\
\text { percent }\end{array}$ & $\begin{array}{c}\delta^{13} \mathrm{C}_{\text {organic }} \\
\left(\% \%_{00}\right)\end{array}$ & $\begin{array}{c}\text { Sample } \\
\text { Depth (cm) } \\
\text { Forams }\end{array}$ & $\begin{array}{l}\text { Interpolated } \\
\text { Age, years }\end{array}$ & $\begin{array}{c}\delta^{18} \mathrm{O} \\
\text { C. ruber (\%or) }\end{array}$ & $\begin{array}{c}\delta^{13} \mathrm{C} \\
\text { G. ruber (\%oo) }\end{array}$ \\
\hline 390 & 126195 & 1.80 & 0.103 & -20.10 & 350 & 110790 & 1.63 & 1.54 \\
\hline 392 & 127382 & 0.78 & 0.043 & -19.34 & 360 & 114409 & 0.92 & 1.25 \\
\hline 394 & 128569 & 0.28 & 0.021 & -19.45 & 370 & 118029 & -0.15 & 0.81 \\
\hline 396 & 129757 & 0.13 & 0.015 & -20.39 & 373 & 119115 & -0.19 & -0.11 \\
\hline 398 & 130944 & 0.11 & 0.014 & -21.10 & 375 & 119838 & -0.38 & 0.16 \\
\hline 400 & 132132 & 0.26 & 0.017 & -21.26 & 377 & 120562 & -1.13 & 0.06 \\
\hline 405 & 135100 & 0.20 & 0.020 & -20.32 & 380 & 121648 & -1.02 & 0.04 \\
\hline 410 & 136536 & 0.15 & 0.012 & -18.79 & 382 & 122372 & -0.10 & 0.11 \\
\hline 420 & 139408 & 0.15 & 0.018 & -19.34 & 384 & 123096 & -1.22 & 0.02 \\
\hline 430 & 142280 & 0.12 & 0.015 & -19.85 & 386 & 123820 & -1.42 & -0.01 \\
\hline 440 & 149728 & 0.06 & 0.010 & -20.32 & 388 & 125007 & -1.32 & 0.15 \\
\hline 450 & 157175 & 1.92 & 0.115 & -21.80 & 390 & 126195 & -1.12 & 0.31 \\
\hline 460 & 164623 & 1.20 & 0.071 & -20.95 & 392 & 127382 & 0.22 & 1.09 \\
\hline 462 & 166113 & 0.15 & 0.017 & -18.98 & 394 & 128569 & 0.34 & 1.14 \\
\hline 464 & 167602 & 2.13 & 0.132 & -22.20 & 396 & 129757 & 0.78 & 1.28 \\
\hline 466 & 169092 & 1.96 & 0.117 & -22.15 & 398 & 130944 & 0.40 & 1.41 \\
\hline 468 & 170581 & 2.41 & 0.143 & -22.29 & 400 & 132132 & 1.61 & 1.16 \\
\hline 470 & 172071 & 2.31 & 0.131 & -22.49 & 405 & 135100 & 2.48 & 1.22 \\
\hline 472 & 173560 & 2.24 & 0.135 & -22.80 & 410 & 136536 & 2.08 & 1.03 \\
\hline 474 & 175050 & 2.43 & 0.151 & -20.72 & 420 & 139408 & 0.99 & 1.14 \\
\hline 476 & 176081 & 3.15 & 0.174 & -22.45 & 430 & 142280 & 0.51 & 0.77 \\
\hline 478 & 177112 & 2.03 & 0.121 & -21.30 & 440 & 149728 & 1.39 & 1.05 \\
\hline 480 & 178144 & 0.41 & 0.031 & -20.61 & 450 & 157175 & 0.62 & 1.18 \\
\hline 485 & 180722 & 0.23 & 0.022 & -20.67 & 460 & 164623 & 0.43 & 0.87 \\
\hline 490 & 183300 & 0.22 & 0.020 & -18.91 & 474 & 175050 & 0.40 & 1.02 \\
\hline 495 & 184928 & 0.23 & 0.019 & -18.83 & 476 & 176081 & 0.46 & 1.11 \\
\hline 500 & 186557 & 0.22 & 0.026 & -19.31 & 478 & 177112 & 0.71 & 0.78 \\
\hline 505 & 188185 & 0.57 & 0.037 & -19.57 & 480 & 178144 & 0.34 & 1.02 \\
\hline 510 & 189813 & 0.64 & 0.039 & -19.63 & 485 & 180722 & 1.21 & 0.97 \\
\hline 515 & 191442 & 4.35 & 0.253 & -21.19 & 490 & 183300 & 1.53 & 0.83 \\
\hline 517 & 192093 & 3.98 & 0.230 & -20.92 & 495 & 184928 & 1.00 & 0.99 \\
\hline 520 & 193070 & 4.35 & 0.244 & -20.84 & 505 & 188185 & 0.81 & 1.20 \\
\hline 522 & $193570^{\circ}$ & 4.31 & 0.243 & -20.89 & 510 & 189813 & 0.69 & 1.08 \\
\hline 524 & 194070 & 3.99 & 0.225 & -20.89 & 515 & 191442 & -1.36 & 0.87 \\
\hline 526 & 194570 & 3.77 & 0.197 & -20.55 & 517 & 192093 & -1.56 & 0.68 \\
\hline 528 & 195070 & 3.12 & 0.170 & -20.44 & 520 & 193070 & -1.81 & 0.88 \\
\hline 530 & 195570 & 1.94 & 0.110 & -20.87 & 522 & 193570 & -1.52 & 0.69 \\
\hline 532 & 196070 & 2.16 & 0.119 & .20 .78 & 524 & 194070 & -1.28 & 0.34 \\
\hline 534 & 196570 & 1.09 & 0.059 & -19.42 & 526 & 194570 & -1.66 & 0.71 \\
\hline 536 & 197070 & 0.65 & 0.044 & -19.34 & 528 & 195070 & -1.64 & 0.95 \\
\hline 538 & 197570 & 0.63 & 0.041 & -19.12 & 530 & 195570 & -0.21 & 0.37 \\
\hline 540 & 198070 & 0.41 & 0.031 & -18.87 & 532 & 196070 & -0.49 & 0.65 \\
\hline 550 & 200570 & 0.15 & 0.017 & -17.94 & 534 & 196570 & 0.65 & 0.85 \\
\hline 560 & 206328 & 0.25 & 0.019 & -17.53 & 536 & 197070 & 0.67 & 1.25 \\
\hline 565 & 209207 & 0.23 & 0.029 & -18.82 & 538 & 197570 & 0.71 & 1.22 \\
\hline 567 & 210358 & 1.69 & 0.087 & -19.69 & 540 & 198070 & 1.05 & 1.06 \\
\hline 568 & 210934 & 1.29 & 0.072 & -20.25 & 550 & 200570 & 1.22 & 1.14 \\
\hline 570 & 213237 & 1.29 & 0.076 & -20.25 & 560 & 206328 & -0.13 & 1.22 \\
\hline 572 & 213813 & 0.74 & 0.045 & -19.65 & 565 & 209207 & -0.10 & 0.60 \\
\hline 574 & 214389 & 0.57 & 0.041 & -18.54 & 567 & 210358 & -0.06 & 0.41 \\
\hline 576 & 215540 & 0.78 & 0.054 & -20.57 & 568 & 210934 & -0.30 & 0.66 \\
\hline 578 & 216090 & 0.80 & 0.053 & -20.62 & 572 & 213237 & -0.46 & 0.53 \\
\hline 580 & 216640 & 0.86 & 0.055 & -20.70 & 574 & 214389 & -1.24 & 0.17 \\
\hline 582 & 217190 & 1.32 & 0.074 & -21.92 & 575 & 214964 & -1.67 & 1.07 \\
\hline 584 & 217740 & 1.59 & 0.091 & -22.18 & 576 & 215540 & -1.70 & -0.06 \\
\hline $\begin{array}{l}586 \\
588\end{array}$ & $\begin{array}{l}218290 \\
218840\end{array}$ & $\begin{array}{l}2.93 \\
2.36\end{array}$ & $\begin{array}{l}0.153 \\
0.141\end{array}$ & $\begin{array}{l}-21.52 \\
-23.02\end{array}$ & $\begin{array}{l}580 \\
582\end{array}$ & $\begin{array}{l}216640 \\
217190\end{array}$ & $\begin{array}{r}-1.60 \\
2.12\end{array}$ & $\begin{array}{l}-0.03 \\
0.22\end{array}$ \\
\hline 590 & 219390 & 2.52 & 0.139 & -21.81 & 584 & 217740 & 1.73 & 0.58 \\
\hline 592 & 219940 & 2.25 & 0.135 & -22.85 & 586 & 218290 & -1.05 & -0.09 \\
\hline 594 & 220490 & 2.05 & 0.121 & -21.86 & 590 & 219390 & -0.54 & 0.57 \\
\hline 596 & 221040 & 0.39 & 0.032 & -19.49 & 592 & 219940 & -0.61 & 0.80 \\
\hline 600 & 222140 & 0.38 & 0.028 & -19.67 & 594 & 220490 & -2.33 & 0.61 \\
\hline 610 & 224890 & 0.19 & 0.018 & -19.18 & 596 & 221040 & -0.46 & 0.66 \\
\hline 620 & 230354 & 0.21 & 0.026 & -19.27 & 600 & 222140 & 0.24 & 0.79 \\
\hline 630 & 235818 & 2.41 & 0.142 & -20.64 & 610 & 224890 & 1.64 & 0.82 \\
\hline 632 & 236911 & 2.51 & 0.136 & -20.51 & 620 & 230354 & 0.71 & 1.33 \\
\hline 634 & 238004 & 2.13 & 0.125 & -20.57 & 630 & 235818 & -0.14 & 0.37 \\
\hline 636 & 239097 & 0.62 & 0.050 & -18.43 & 632 & 236911 & 0.01 & 0.27 \\
\hline 638 & 240190 & 0.50 & 0.040 & -18.17 & 634 & 238004 & 0.50 & 0.32 \\
\hline
\end{tabular}


Fontugne and Calvert: Mediterranean ${ }^{13} \mathrm{C}_{\text {organic }}$ Variations

TABLE 1.(contunued)

\begin{tabular}{|c|c|c|c|c|c|c|c|c|}
\hline $\begin{array}{c}\text { Sample } \\
\text { Depth (cm) } \\
\text { Chemistry } \\
\end{array}$ & $\begin{array}{l}\text { Interpolated } \\
\text { Age, years }\end{array}$ & $\begin{array}{c}\text { Organic C } \\
\text { percent }\end{array}$ & $\begin{array}{l}\text { Tolal N } \\
\text { percent }\end{array}$ & $\begin{array}{c}\bar{\delta}^{13} \mathrm{C}_{\text {organic }} \\
(\% \mathrm{cos})\end{array}$ & $\begin{array}{c}\text { Sample } \\
\text { Deph (cm) } \\
\text { Forarns } \\
\end{array}$ & $\begin{array}{l}\text { Inicrpolaled } \\
\text { Age, years }\end{array}$ & $\begin{array}{c}\delta^{18} \mathrm{O} \\
\text { G. ruber }(\%)\end{array}$ & $\begin{array}{c}\delta^{13} \mathrm{C} \\
\text { G. ruber (\%o) }\end{array}$ \\
\hline 640 & 240610 & 0.46 & 0.040 & -18.17 & 636 & 239097 & 0.19 & 1.09 \\
\hline 645 & 241658 & 0.43 & 0.032 & -17.60 & 638 & 240190 & 0.76 & 1.14 \\
\hline 650 & 242707 & 0.41 & 0.030 & -16.82 & 640 & 240610 & 0.18 & 1.44 \\
\hline 660 & 244805 & 0.25 & 0.022 & -17.74 & 645 & 241658 & -0.27 & 1.88 \\
\hline 670 & 246902 & 0.36 & 0.022 & -17.73 & 650 & 242707 & 0.56 & 1.66 \\
\hline 680 & 249000 & 0.23 & 0.023 & -18.25 & 660 & 244805 & 0.80 & 1.14 \\
\hline 690 & 253000 & 0.22 & 0.023 & -17.94 & 670 & 246902 & 1.44 & 1.14 \\
\hline 700 & 257000 & 0.18 & 0.023 & -18.47 & 680 & 249000 & 1.46 & 1.00 \\
\hline 710 & 259890 & 0.19 & 0.022 & -18.70 & 690 & 253000 & 1.23 & 1.20 \\
\hline 720 & 262780 & 0.18 & 0.023 & -19.33 & 700 & 257000 & 1.11 & 0.81 \\
\hline 730 & 265670 & 0.21 & 0.021 & -18.69 & 710 & 259890 & 1.96 & 1.23 \\
\hline 740 & 270244 & 0.22 & 0.023 & -19.61 & 720 & 262780 & 1.73 & 1.19 \\
\hline 750 & 274818 & 0.15 & 0.022 & -18.20 & 730 & 265670 & 1.65 & 1.19 \\
\hline 760 & 279392 & 0.21 & 0.020 & -21.57 & 740 & 270244 & 1.93 & 1.38 \\
\hline 770 & 283966 & 0.17 & 0.029 & -19.08 & 750 & 274818 & 0.84 & 1.39 \\
\hline 780 & 288540 & 0.19 & 0.022 & -18.59 & 760 & 279392 & 0.86 & 1.48 \\
\hline 790 & 292027 & 0.15 & 0.019 & -20.42 & 770 & 283966 & 0.92 & 1.31 \\
\hline 800 & 295513 & 0.12 & 0.022 & -19.21 & 780 & 288540 & 0.26 & 1.75 \\
\hline 810 & 299000 & 0.12 & 0.019 & -19.35 & 790 & 292027 & 0.76 & 1.75 \\
\hline 820 & 302667 & 0.17 & 0.023 & -19.80 & 800 & 295513 & 1.46 & 1.21 \\
\hline 830 & 306333 & 0.15 & 0.017 & -19.24 & 810 & 299000 & 1.62 & 0.91 \\
\hline 840 & 310000 & 0.19 & 0.021 & -20.33 & 820 & 302667 & 0.70 & 1.14 \\
\hline 850 & 313333 & 0.30 & 0.025 & -18.99 & 830 & 306333 & 0.94 & 1.72 \\
\hline 857 & 315667 & 0.35 & 0.027 & -18.81 & 840 & 310000 & -0.16 & 1.79 \\
\hline 859 & 316333 & 0.33 & 0.025 & -18.78 & 850 & 313333 & 1.04 & 1.21 \\
\hline 864 & 318000 & 0.29 & 0.031 & -19.33 & 857 & 315667 & 0.28 & 1.07 \\
\hline 870 & 320000 & 0.05 & 0.033 & -18.59 & 859 & 316333 & 0.75 & 1.01 \\
\hline 880 & 321897 & 0.15 & 0.019 & -19.21 & 864 & 318000 & 1.15 & 1.75 \\
\hline 890 & 323793 & 0.14 & 0.016 & -19.98 & 870 & 320000 & 1.59 & 1.42 \\
\hline 900 & 325690 & 0.13 & 0.015 & -19.77 & 880 & 321897 & 1.26 & 1.21 \\
\hline 910 & 327586 & 0.13 & 0.019 & -21.04 & 890 & 323793 & 0.56 & 1.29 \\
\hline 918 & 329103 & 0.35 & 0.029 & -19.95 & 900 & 325690 & -0.01 & 1.33 \\
\hline 920 & 329483 & 1.66 & 0.098 & -20.79 & 910 & 327586 & 0.02 & 0.75 \\
\hline 922 & 329862 & 2.10 & 0.126 & -20.74 & 918 & 329103 & 0.30 & 0.57 \\
\hline 924 & 330241 & 2.05 & 0.119 & -20.93 & 922 & 329862 & 1.10 & 0.91 \\
\hline 926 & 330621 & 2.48 & 0.148 & -21.17 & 924 & 330241 & 0.60 & 0.63 \\
\hline 928 & 331000 & 2.56 & 0.153 & -20.81 & 926 & 330621 & 1.54 & 1.09 \\
\hline 930 & 332121 & 1.90 & 0.122 & -20.52 & 928 & 331000 & -0.03 & 0.31 \\
\hline 934 & 334364 & 0.52 & 0.041 & -19.34 & 930 & 332121 & 0.42 & 1.13 \\
\hline 940 & 337727 & 0.52 & 0.040 & -19.75 & 934 & 334364 & 0.89 & 0.74 \\
\hline 950 & 343333 & 0.36 & 0.026 & -18.90 & 940 & 337727 & -0.34 & 1.00 \\
\hline 960 & 348939 & 0.22 & 0.029 & -17.37 & 950 & 343333 & 1.92 & 0.79 \\
\hline 970 & 354545 & 0.21 & 0.014 & -18.74 & 960 & 348939 & 0.72 & 0.65 \\
\hline 980 & 360151 & 0.12 & 0.015 & -17.18 & 970 & 354545 & 1.15 & 1.05 \\
\hline 990 & 365757 & 0.13 & 0.018 & -16.62 & 980 & 360151 & 1.65 & 0.94 \\
\hline 1000 & 371363 & 0.27 & 0.019 & -17.37 & 990 & 365757 & 1.34 & 1.49 \\
\hline 1010 & 376969 & 0.19 & 0.019 & -17.93 & 1000 & 371363 & 1.40 & 1.35 \\
\hline 1020 & 382575 & 0.30 & 0.018 & -18.24 & 1010 & 376969 & 1.50 & 1.48 \\
\hline $\begin{array}{l}1030 \\
1040\end{array}$ & $\begin{array}{l}388181 \\
393787\end{array}$ & $\begin{array}{l}0.26 \\
0.22\end{array}$ & $\begin{array}{l}0.020 \\
0.019\end{array}$ & $\begin{array}{l}-17.62 \\
-18.71\end{array}$ & $\begin{array}{l}1020 \\
1030\end{array}$ & $\begin{array}{l}382575 \\
388181\end{array}$ & $\begin{array}{l}1.40 \\
1.73\end{array}$ & $\begin{array}{l}1.41 \\
1.31\end{array}$ \\
\hline 1050 & 399393 & 0.22 & 0.019 & -18.55 & 1040 & 393787 & 1.22 & 1.22 \\
\hline 1060 & 404999 & 0.25 & 0.016 & -18.56 & 1050 & 399393 & 1.41 & 1.36 \\
\hline 1070 & 410606 & 0.26 & 0.019 & -19.81 & 1060 & 404999 & 0.75 & 1.40 \\
\hline 1080 & 416212 & 0.19 & 0.017 & -18.56 & 1070 & 410606 & 0.25 & 1.35 \\
\hline 1090 & 421818 & 0.18 & 0.018 & -18.84 & 1080 & 416212 & 0.38 & 1.36 \\
\hline 1100 & 427424 & 0.11 & 0.019 & -18.77 & 1090 & 421818 & 1.19 & 1.63 \\
\hline 1110 & 433030 & 0.19 & 0.025 & -19.01 & 1100 & 427424 & 1.54 & 1.71 \\
\hline 1120 & 438636 & 0.19 & 0.020 & -18.08 & 1110 & 433030 & 1.49 & 1.78 \\
\hline 1130 & 444242 & 0.18 & 0.021 & -19.19 & 1120 & 438636 & 1.11 & 1.39 \\
\hline 1140 & 449848 & 0.19 & 0.010 & -18.94 & 1130 & 444242 & 1.47 & 1.60 \\
\hline 1150 & 455454 & 0.21 & 0.019 & -19.73 & 1140 & 449848 & 1.08 & 1.56 \\
\hline \multirow[t]{2}{*}{1160} & 461060 & 0.27 & 0.021 & -18.40 & 1150 & 455454 & 0.98 & 1.69 \\
\hline & & & & & 1160 & 461060 & 1.39 & 1.79 \\
\hline
\end{tabular}




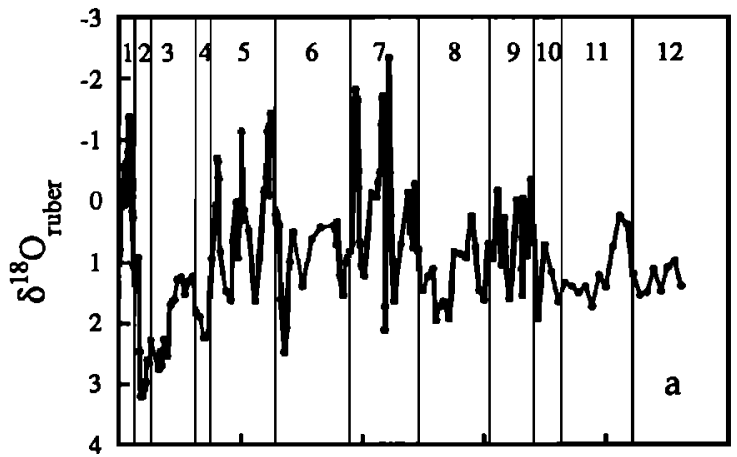

Fig. 2a. The $\delta^{18} \mathrm{O}_{\text {ruber record in core }} \mathrm{MD} 84641$. Stage boundaries were identified on the basis of correlation with the Specmap stack [Martinson et al., 1987].

core appears to extend back to Stage 12 as defined by Emiliani [1955]. The last glacial maximum (Stage 2) has $\delta^{18} \mathrm{O}$ values of more than $3 \%$, whereas Stage 8 shows values close to $2 \%$. The lightest $\delta^{18} \mathrm{O}$ values are found in Stage 7. The magnetic reversal Blake Event (beginning at $117 \mathrm{Ka}$ ) occurs at $367-375 \mathrm{~cm}$ depth in the core[Fontugne et al., 1989a; Tucholka et al., 1987], consistent with the isotope stratigraphy (Figure 2a).

The $\delta^{13} C_{\text {ruber }}$ record (Figure $2 b$ ) shows that the planktonic carbon isotopic composition also varies between wide limits throughout the core. Most noteworthy are the large negative excursions of the $\delta^{13} \mathrm{C}$ values in eight of the nine sapropels. The largest of these excursions occurs in S8, where values of $-0.11 \% \circ$ are found. Sapropel S6 shows only a very small negative excursion from the horizon immediately below S5 to the horizon immediately above $\mathbf{S 7}$. Sapropel $\mathrm{S} 10$ has a clear $\delta^{13} \mathrm{C}$ signal in spite of the fact that the $\delta^{18} \mathrm{O}_{\text {ruber }}$ amplitude at this depth is rather subdued (Figure 2a).

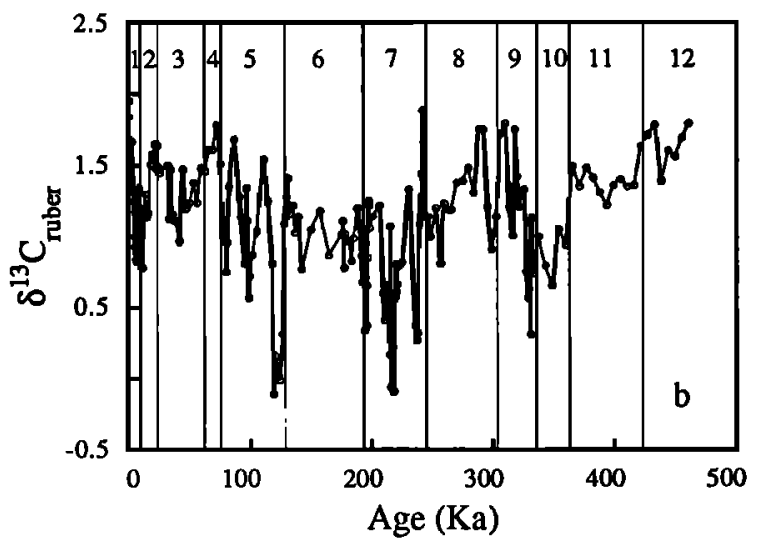

Fig. 2b. The $\delta^{13} C_{\text {ruber record in core }} \mathrm{MD} 84641$.

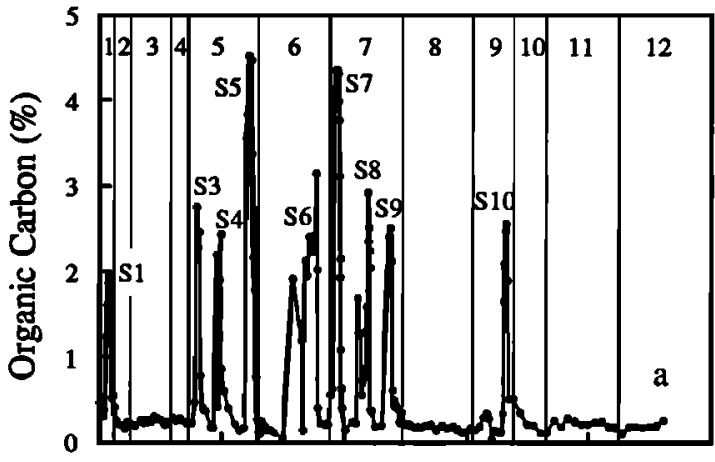

Fig. 3a. Distribution of organic carbon plotted against age derived from the foraminiferal stratigraphy shown in Figure 2a. The sapropel horizons are labelled S1 and S3-S10 [Cita et al., 1977].

The age model for this core yields sedimentation rates of between 1.34 and $5.28 \mathrm{~cm} / \mathrm{kyr}$ These are fairly similar to those reported for this part of the eastern Mediterranean by Stanley and Maldonado [1977].

Comparison between the organic carbon (Figure 1a) and $\delta^{18} \mathrm{O}_{\text {ruber }}$ records (Figure $2 \mathrm{a}$ ) demonstrates that core MD 84641 contains sapropels S1 and S3S10 [Cita et al., 1977]. Sapropel S2 appears to be missing (Figure 3a), as is often the case [RossignolStrick, 1985] for this rather poorly developed interglacial stage. The magnetic reversal Blake Event (beginning at $117 \mathrm{Ka}$ ) occurs between $\mathrm{S} 4$ and S5 [Tucholka et al., 1987].

The $\delta^{13} C_{\text {organic }}$ record (Figure $3 b$ ) shows that there is a very large variation in the isotopic composition of the organic matter in this core, with a total amplitude of more than $6 \%$. The values are systematically lighter in all sapropel horizons, with values reaching $-23 \%$ in $S 8$, and the heaviest values are confined to the glacial stages; values as heavy as $16 \%$ are found in stages 2,8 , and 10 . In detail, the

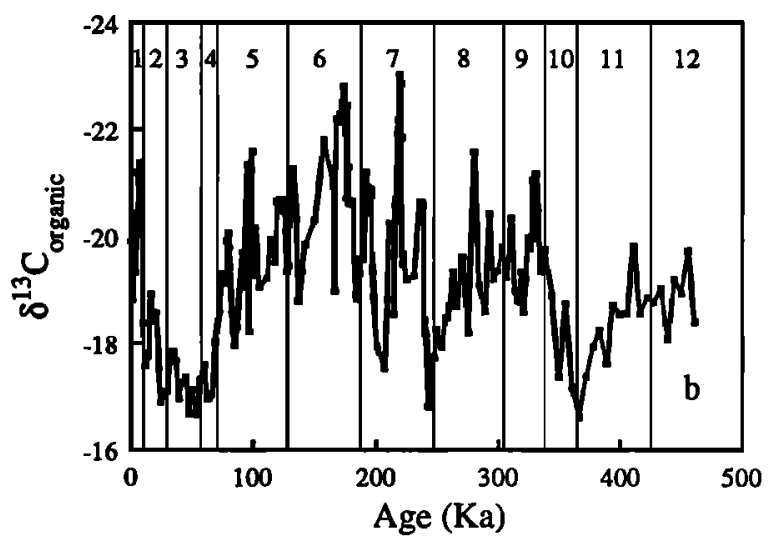

Fig. 3b. The $\delta^{13} C_{\text {organic record in core } \mathrm{MD} 84641 .}$ 
variations in $\delta^{13} \mathrm{C}_{\text {organic }}$ closely follow those of the concentration of organic C; in sapropels S3, S4, S5, and $S 8$ there are minima in organic $C$ between two maxima, and the $\delta^{13} C_{\text {organic }}$ values are seen to change abruptly to heavier values at these same horizons (Figure $3 b$ ).

\section{INTERPRETATION}

The detailed compositional and isotopic records in core $\mathrm{MD} 84641$ show that the sapropels have higher $\mathrm{C}_{\text {organic }} \mathrm{N}$ ratios and lighter $\delta^{13} \mathrm{C}$ values than the intercalated marl oozes and that the $\delta^{13} \mathrm{C}_{\text {organic }}$ values in the glacial maximum horizons are significantly heavier than in any other part of the core.

The variation in the ${ }^{13} \mathrm{C} /{ }^{12} \mathrm{C}$ ratio of organic matter in marine sediments has in the past been ascribed to one of three factors: (1) variable mixtures of carbon derived from marine and terrestrial sources, (2) diagenetic changes in the isotopic composition of the deposited organic material, and (3) variations in the isotopic composition of the marine organic material.

\section{Terrestrial Versus Marine Contributions}

In most sedimentary environments, marine planktonic organic carbon is isotopically heavier than that of the carbon delivered to the ocean from terrestrial environments. Solution of the simple mixing equation $\delta^{13} \mathrm{C}=\mathrm{F}_{\mathrm{t}} * \delta^{13} \mathrm{C}_{\mathrm{t}}+\mathrm{F}_{\mathrm{m}} * \delta^{13} \mathrm{C}_{\mathrm{m}}$, with $F_{m}+F_{t}=1$, where $F_{t}$ and $F_{m}$ are the fractions of terrestrial and marine organic matter and $\delta^{13} \mathrm{C}_{\mathrm{l}}$ and $\delta^{13} C_{m}$ are the isotopic compositions of the terrestrial and marine organic carbon sources, respectively, provides a method for estimating the proportions of the two types of organic matter present in a given sample [Calder and Parker, 1968]. Making such estimates requires an accurate knowledge of the isotopic compositions of the marine and terrestrial end-members. Published information on the isotopic composition of terrestrial vegetation (summarized by Deines [1980]) shows that plants fall into two categories depending on the initial carbon fixing pathway during photosynthesis. These are $\mathrm{C}_{3}$ plants that use ribulose bisphosphate carboxylaseoxygenase (RUBISCO) as the carboxylating enzyme and which have $\delta^{13} \mathrm{C}$ values that cluster around a modal value of $-27 \%$, and $\mathrm{C}_{4}$ plants that use phospoenolpyruvate carboxylase (PEPC) as the initial carboxylating enzyme with $\delta^{13} \mathrm{C}$ values close to $-14 \%$. Studies of the input of terrestrial plant debris into the nearshore regions of the ocean [Sackett and Thompson, 1963; Sackett, 1964; Gearing et al., 1977; Tan and Strain, 1979a; 1983; Salomons and Mook, 1981; Fontugne and Jouanneau, 1987] have shown that, with few exceptions, the terrestrial isotopic signal is that of $C_{3}$ plants; $C_{4}$ plants (sea grasses, etc.) can contribute significantly to the sediments in some coastal lagoons [Parker, 1964; Shultz and Calder, 1976] and reef tracts [Rasmussen et al., 1990], but the effect of such sources appears to be areally restricted. In order to have an important effect in core MD 84641, a contribution of more than $50 \%$ of the organic matter from pure $\mathrm{C}_{4}$ plants would be required to produce the heavy $\delta^{13} \mathrm{C}$ values in stages $2,4,8$, and 10 (Figure 3b). The pollen record from the neighbouring core MD $84642\left(32^{\circ} 41^{\prime} \mathrm{N}, 32^{\circ} 35^{\prime} \mathrm{E}\right.$, $1260 \mathrm{~m}$ ) shows that gramminea, which are potential $\mathrm{C}_{4}$ plant contributors, represent less than $20 \%$ of pollen content which itself has a low abundance $(<150 / \mathrm{g})$ [Cheddadi, 1988]. It is unlikely therefore that the contrast in the $\delta^{13} \mathrm{C}$ values between the sapropels and the marl oozes is produced by the variable admixture of $\mathrm{C}_{3}$ and $\mathrm{C}_{4}$ plant debris. We do not have measurements of the isotopic composition of the carbon being supplied to the Mediterranean Sea from the surrounding land areas, but we have assumed that its $\delta^{13} \mathrm{C}$ value is close to $-27 \%$ [Deines, 1980], which is characteristic of $C_{3}$ type plants of the temperate zone and similar to that of estuarine particulate organic carbon [Tan and Strain, 1979a,1979b; Salomons and Mook, 1981; Fontugne and Jouanneau, 1987; Saliot et al., 1988]. Only very small changes in the isotopic composition of terrestrial organic material have been recorded during glacial to interglacial transitions [Fontugne and Duplessy, 1986], so that the isotopic composition of this source material is not likely to have varied significantly.

In contrast to the relatively constant value for the isotopic composition of the terrestrial organic matter supply to offshore marine sediments, some important variations have been reported for marine planktonic organic material [Müller et al., 1983; Fontugne and Duplessy, 1986; Sarnthein et al., 1988; Jasper and Hayes, 1990] so that it is difficult to specify uniquely the isotopic signature of this source. These $\delta^{13} \mathrm{C}$ changes have been attributed to (1) sea surface temperature variations [Sackett et al., 1965; Fontugne and Duplessy, 1981], (2) water mass characteristics [Fontugne and Duplessy, 1978], (3) metabolic effects depending on the photosynthetic pathway [Descolas-Gros and Fontugne, 1985, 1990b], 4) phytoplankton species distribution [Fontugne, 1983], and (5) variations in the concentration of dissolved $\mathrm{CO}_{2}$ in seawater [Rau et al., 1989]. The range of variation is around $10 \%$, so that this may lead to very large uncertainties in the determination of the terrestrial versus marine carbon flux to the deep ocean.

In the Mediterranean Sea, modern plankton has ${ }^{13} \mathrm{C}$ values ranging between $-24.5 \%$ in Alboran Sea winter plankton and -22\%o in Eastern Mediterranean winter plankton [Fontugne, 1983], regardless of the 
proportion of phytoplankton and zooplankton in the samples. The latter is identical to values of $-22 \%$ o reported by Deuser [1970] in the Black Sea. Hence in the sapropels in core MD 84641, where $\delta^{13} \mathrm{C}$ has a mean value of $-21.0 \pm 0.8 \%$, the contribution of terrestrial organic matter to the bulk organic matter must be very small. Moreover, it must be even smaller in the marl oozes, where the $\delta^{13} \mathrm{C}$ values are even heavier $(-18.84 \pm 1.1 \%)$. The conclusion that we are dealing with a predominantly marine source of organic matter in the sapropels is consistent with the predominantly marine source of the lipids in S1 reported by Smith et al. [1986] and Ten Haven et al. [1987].

Further support for the absence of a significant terrestrial contribution to the sapropels is the absence of a gradient in $\delta^{13} \mathrm{C}$ over the whole eastern Mediterranean between the potential source areas of terrestrial supplies, such as the Nile river, and the central parts of the basin (see Table 2). Such a pattern is also encountered in the Black Sea sapropel [Calvert and Fontugne, 1987]. Finally, Ten Haven et al. [1987] have shown that the $\delta^{13} C_{\text {organic }}$ values of sapropel $\$ 6$ are significantly more negative than those of other sapropels, while the terrigenous fraction, as estimated from the presence of organic biomarkers, is no different from that in other sapropels. Moreover, these authors show that a relative increase in marine biomarkers corresponds with more negative $\boldsymbol{\delta}^{13} C_{\text {organic }}$ values.

The organic $\mathrm{C} / \mathrm{N}$ ratio of organic matter is also considered to be a useful indicator of the origin of organic matter in marine sediments [Stevenson and Cheng, 1972]. Values between 6 and 7 by weight reflect the presence of planktonic organic matter [Redfield et al., 1963], whereas typical terrestrial plants exhibit values greater than 20 [Hedges et al., 1986]. In core $\mathrm{MD} 84641$, the $\mathrm{C}_{\text {organid }} \mathrm{N}$ ratios are higher $($ mean $=16.9 \pm 1.1 ; n=63)$ in the sapropels compared with the marl oozes (mean $=12.3 \pm 4.1$; $n$ $=135$ ). Hence, solely on basis of the $\mathrm{C} / \mathrm{N}$ ratio, one could conclude that both the sapropels and the marl oozes contain a mixture of marine and terrestrial organic matter and that terrestrial organic matter constitutes a larger fraction of the total in the

TABLE 2. $8^{13} \mathrm{C}_{\text {organic }}$ Values in Sapropels From Other Eastern Mediterranean Sites

\begin{tabular}{|c|c|c|c|c|c|c|c|c|c|}
\hline Core & S1 & S3 & S4 & 55 & 56 & S7 & 58 & S9 & S10 \\
\hline $\begin{array}{l}\text { DED 8708 } \\
39^{\circ} 42^{\prime} \mathrm{N} ; 13^{\circ} 34 \mathrm{E} \\
2965 \mathrm{~m}\end{array}$ & & & -22.35 & -22.09 & & -23.24 & -21.36 & -22.30 & -21.64 \\
\hline $\begin{array}{l}\text { DI } 10103 / 8 \mathrm{~K} \\
36^{\circ} 10 \mathrm{~N} ; 20^{\circ} 40 \mathrm{E} \\
2900 \mathrm{~m}\end{array}$ & $\begin{array}{l}-21.30 \\
-21.00 \\
-21.60\end{array}$ & & & & & & & & \\
\hline $\begin{array}{l}\text { TR } 83-7 \\
33^{\circ} 39.7^{\prime} \mathrm{N} ; 25^{\circ} 59^{\prime} \mathrm{E} \\
2480 \mathrm{~m}\end{array}$ & & & & & -22.70 & $\begin{array}{l}-22.00 \\
-22.50\end{array}$ & & & \\
\hline $\begin{array}{l}\text { TR } 83-30 \\
33^{\circ} 48 \mathrm{~N} ; 28^{\circ} 36.6^{\mathrm{E}} \\
2810 \mathrm{~m}\end{array}$ & .22 .60 & & & & & & & & \\
\hline $\begin{array}{l}\text { MD 84639 } \\
33^{\circ} 40^{\prime} \mathrm{N} ; 32^{\circ} 42 \mathrm{E} \\
870 \mathrm{~m}\end{array}$ & -21.18 & & & & & & & & \\
\hline $\begin{array}{l}\text { MD 84642 } \\
32^{\circ} 40^{\prime} \mathrm{N} ; 3234 \mathrm{E} \\
1260 \mathrm{~m}\end{array}$ & -21.20 & $\begin{array}{l}-19.84 \\
-19.51\end{array}$ & $\begin{array}{l}-21.07 \\
-20.93 \\
-21.06\end{array}$ & $\begin{array}{l}-22.47 \\
-21.59\end{array}$ & -21.59 & & & & \\
\hline $\begin{array}{l}\text { MD 84641 } \\
32^{\circ} 40^{\circ} \mathrm{N} ; 32^{\circ} 34^{\prime} \mathrm{E} \\
1375 \mathrm{~m}\end{array}$ & -20.80 & -19.80 & -20.64 & -20.58 & -22.44 & -20.82 & -22.17 & -20.57 & -20.83 \\
\hline $\begin{array}{l}\text { MD } 84629 \\
32^{\circ} 13^{\prime} \mathrm{N} ; 33^{\circ} 45 \mathrm{E} \\
745 \mathrm{~m}\end{array}$ & -20.88 & & & & & & & & \\
\hline
\end{tabular}




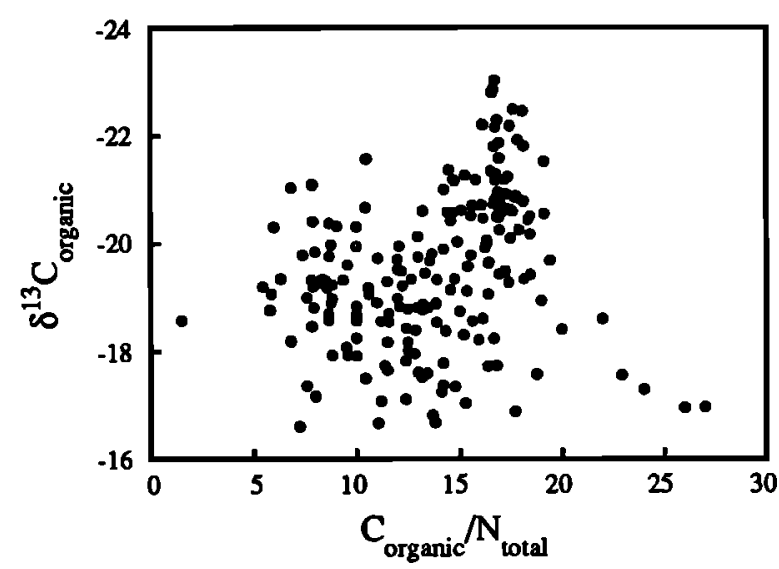

Fig. 4. Relationship between $\delta^{13} C_{\text {organic }}$ and the $\mathrm{C}_{\text {organid }} \mathrm{N}$ ratio in core MD84641.

sapropels. In spite of a clear difference in the $\mathrm{C}_{\text {organic }} \mathrm{N}$ ratio between the two lithologies, the degree of correlation between $\mathrm{C}_{\text {organic }} / \mathrm{N}$ and $\delta^{13} \mathrm{C}$ is quite poor (Figure 4). The lower $\mathrm{C} / \mathrm{N}$ ratios in the marl oozes are probably partly caused by the presence of a large amount of adsorbed inorganic $\mathbf{N}$ relative to total $\mathrm{N}$ in these organic-poor sediments [Müller, 1977]. In addition, Suess and Müller [1980] have shown that the organic $\mathrm{C} / \mathrm{N}$ ratio of sedimentary organic matter in high-productivity environments is much higher than that deposited under oligotrophic conditions. This is due to the preferential removal of nitrogenous organic material during particle settling and prior to burial and the contribution of nitrogen to the sediment by benthic organisms. These processes could contribute to the difference in the $\mathrm{C} / \mathrm{N}$ ratio of the two facies in core MD 84641 if the marl oozes represent the deposits of an oligotrophic basin, like the present situation, and the sapropels represent the deposits of high-productivity conditions, as argued by Calvert $[1983,1987]$ and Sutherland et al. [1984]. These complicating factors imply that we cannot use these $\mathrm{C} / \mathrm{N}$ data to infer organic matter sources in this core.

\section{Effects of Diagenesis}

The carbon isotopes are not uniformly distributed among all components of sedimentary organic matter. Differences of up to 7\%o have been reported, for example, between the lignin and cellulose fractions of marine sediments [Benner et al., 1987]. It is also known that the various components of sedimentary organic matter are decomposed at different rates, so that the bulk $\delta^{13} \mathrm{C}$ value of organic matter can change differentially with diagenesis. Although Sackett [1964], Rogers and Koons [1969], and Dean et al. [1986] discounted the effects of diagenetic alteration of the carbon isotopic composition of sedimentary organic matter, there is evidence for some changes in this signal. Spiker and Hatcher [1984] showed that the bulk $\delta^{13} \mathrm{C}$ values of algal sapropelic sediment accumulating in Mangrove Lake, Bermuda changed by $4 \%$ over the last 5000 years. They attributed a somewhat irregular change to lighter $\delta^{13} \mathrm{C}$ values at the base of a marine sapropel horizon to the preferential degradation of the carbohydrate fraction (being relatively enriched in ${ }^{13} \mathrm{C}$ ) which caused the residual organic material, which was enriched in humin, to become depleted in ${ }^{13} \mathrm{C}$. Dean et al., [1986] pointed out, however, that the environment in this lake has changed from freshwater to marine conditions during this time interval, and the isotopic composition of the dissolved inorganic carbon, as shown by the $\delta^{13} \mathrm{C}$ values of carbonate shell remains, has also changed in parallel with the changes in the isotopic composition of the organic matter. They suggested therefore that the observed change may be due to a change in the source of $\mathrm{CO}_{2}$ (and hence its $\delta^{13} \mathrm{C}$ value) and not necessarily to diagenesis.

McArthur et al. [1991] found a ${ }^{13} \mathrm{C}$ depletion of $2.5 \%$ in the organic fraction of the upper, oxidized compared with the lower, unoxidized portion of a turbidite from the northeatern Atlantic, and they explained this by the different degrees of alteration of bulk planktonic organic matter which has been supplied to the abyssal seafloor from the neighbouring slope region. Such isotopic change occurs in this situation only after a time interval of several thousand years, because McArthur et al. [1991] were not able to detect a significant change in $\delta^{13} \mathrm{C}_{\text {organic }}$ in a second turbidite that had been exposed to oxygen for only 200 years.

Glacial to interglacial cyclic variations in $\delta^{13} \mathrm{C}_{\text {organic }}$ in the sediments of the Pigmy Basin (Gulf of Mexico) could not be explained by diagenesis [Jasper and Gagosian, 1990]. These authors demonstrated, from paired isotopic and $N / C_{\text {organic }}$ ratios, that the composition of the organic matter in this basin is a determined by the mixture of $\mathrm{C}_{3}$-terrigenous and marine components which vary on glacial-interglacial time scales. The conclusion that climatically controlled mixing of terrestrial and marine organic matter accounts for the sedimentary isotopic record in this basin confirms the earlier extensive work of Joyce et al. [1985], Neuman et al. [1973], Sackett [1964], and Sackett and Rankin [1970] on the Gulf of Mexico.

Fontugne and Duplessy [1986] also concluded that diagenesis was not substantially involved in producing the $\delta^{13} C_{\text {organic record in late Pleistocene }}$ cores from the Indian Ocean. They showed that, depending on the location of the cores, Holocene sections of cores had both lighter and heavier $\delta^{13} \mathrm{C}$ values compared with late Pleistocene sections, so that there was no consistent secular trend of changing 
isotopic compositions. Moreover, the organic carbon isotopic composition was independent of the total organic carbon content in most of the cores studied. The isotope records in this study were interpreted as a reflection of the balance between marine and terrestrial organic matter supplies to the sediments and the temporal change in the composition of the plankton, whose composition changes with water mass [Fontugne and Duplessy, 1978].

Finally, Hayes et al. [1989] observed a shift in the $\delta^{13} \mathrm{C}$ values of total organic carbon (TOC) compared with those of the Ni-geoporphyrin fraction of a sequence of calcareous shales and limestones of the Cretaceous Greenhorn Formation in the Interior Seaway of western North America. These authors concluded that the $\delta^{13} \mathrm{C}_{\text {porphyrin values closely }}$ reflected the primary planktonic $\delta^{13} \mathrm{C}$ values (offset by $0.5 \%$ ) whereas the $\delta^{13} \mathrm{C}_{\mathrm{TOC}}$ values are further offset because of secondary effects, including foodchain fractionation and sedimentary diagenesis. The inferred isotopic difference between the primary planktonic and the sedimentary organic matter in this rock sequence ranged from 0.6 to $2.8 \%$, although the stratigraphic variations in $\delta^{13} \mathrm{C}_{\mathrm{TOC}}$ closely mirrored those of $\delta^{13} C_{\text {porphyrin }}$.

The combined evidence reviewed here suggests that diagenetic changes in the carbon isotopic composition of sedimentary organic matter of up to $2.8 \% o$ are possible, depending on the environment of sedimentation and the time elapsed since deposited organic matter has been exposed to oxidative degradation. However, such changes are often very difficult to identify, and they would be expected to produce systematic differences between the isotopic composition of the sedimentary organic matter and the planktonic precursor.

Core MD 84641 covers a time period of approximately $450 \mathrm{kyr}$ during which there are three climatic cycles (Figure 2a) and a series of 9 sapropelic events (Figure 3a). The main features of the record are the presence of consistently lighter

$\delta^{13} \mathrm{C}$ values in the sapropels (ranging from -19.4 to $23.0 \%$ ), the heaviest values at the glacial maxima (ranging from -16.6 to $-21.6 \%$ ), and the lack of a secular trend (Figure 3b). Diagenesis would cause the pre-Holocene values to be systematically lighter than they were originally, which would mean that the planktonic organic matter supplied to the sediment during the glacial maxima would have been even more enriched in ${ }^{13} \mathrm{C}$. Moreover, unless the type of organic matter in the sapropels and the marl oozes were significantly different, for which there is no evidence, it is difficult to produce the isotopic contrast between these two lithologies by diagenetic effects alone. The only way that this could happen is by the diagenetic environment in the sediment (oxic in the marl oozes or anoxic in the sapropels) causing the preferential degradation of isotopically lighter organic matter in the marl oozes and/or heavier organic material in the sapropels. There are currently no data available which test this possibility.

We conclude that diagenesis alone cannot be responsible for the large contrast in isotopic values between the sapropels and the marl oozes in core MD 84641 . This is based on the relatively small $(2.8 \%)$ changes that can be definitively produced by diagenesis under certain circumstances and/or over long time periods compared with the $6 \%$ variation that we observe, the lack of a secular trend in the $\delta^{13} C_{\text {organic }}$ record, and the distinct and consistent differences between the two lithologies.

\section{Changes in the Isotopic Composition of Marine Plankton}

If contributions of terrestrial organic matter in core MD 84641 are small and diagenesis cannot explain the large and systematic changes in the isotopic composition of the organic carbon, then the $\delta^{13} \mathrm{C}_{\text {organic }}$ record in core MD 84641 is probably caused by variability of the isotopic composition of the planktonic organic matter produced in the eastern Mediterranean during the time period represented by the core. The isotopic composition of marine planktonic organic matter is known to be variable, and several different factors have been proposed to explain this variability. Descolas-Gros and Fontugne [1990b], Fontugne and Duplessy [1978, 1981] and Sackett et al. [1965] have discussed the temperaturedependent fractionation of carbon isotopes by marine phytoplankton $\left(0.28\right.$ to $\left.0.35 \% /{ }^{\circ} \mathrm{C}\right)$ which leads to an increase of $\delta^{13} \mathrm{C}$ values with increasing sea surface temperature (SST). The trend in core MD 84641 is in the opposite sense, since the heaviest $\delta^{13} \mathrm{C}$ values are found in the glacial maximum horizons when surface water temperatures were roughly $4^{\circ} \mathrm{C}$ lower than at present [Thiede, 1978; Thunell, 1979]. Hence a temperature effect cannot be involved.

A second possibility is that the isotopic composition of the dissolved inorganic carbon (DIC) pool in the eastern Mediterranean has changed over the last 450 $\mathrm{ka}$. The enclosed continental environment of the Mediterranean Sea suggests that changes in the input of fresh water would have an important effect on the nature of the DIC in surface sea water. Fresh water contains mainly dissolved $\mathrm{CO}_{2}$ with a low bicarbonate content; the isotopic composition of the $\Sigma \mathrm{CO}_{2}$ ranges between -5 to $-10 \%$. Seawater, on the other hand, has a high bicarbonate concentration $\left(>90 \%\right.$ of the $\mathrm{\Sigma CO}_{2}$ ) and low dissolved $\mathrm{CO}_{2}$. In the Mediterranean, the isotopic composition of the $\mathrm{\Sigma CO}_{2}$ is around 1.5\%o [Duplessy, 1972]. Between these two end-members the $\delta^{13} \mathrm{C}$ value of $\Sigma \mathrm{CO}_{2}$ varies according to the salinity of the water. A large freshwater input, as shown by the large changes in the $\delta^{18} \mathrm{O}$ values in planktonic foraminifera in the sapropels [Williams et al., 1978; Williams and 
Thunell, 1979], will therefore lower the $\delta^{13} \mathrm{C}$ values of $\Sigma \mathrm{CO}_{2}$ which is used during photosynthesis. The $\delta^{13} C_{\text {ruber }}$ record in core MD84641 (Figure 2b) shows large negative excursions in each sapropel, especially in S5 and S8. The full range of individual values is from 1.95 to $-0.11 \%$. These changes are much larger, and the $\delta^{13} \mathrm{C}$ values are much lighter, than any changes recorded by open ocean planktonic foraminifera, where the differences between glacial and interglacial values are generally less than $0.2 \%$. The markedly light $\delta^{13} \mathrm{C}$ values of $\mathrm{G}$. ruber in the sapropels probably reflect this shift in the isotopic composition of DIC due to mixing of fresh water, and the freshwater contribution could be estimated by comparing the $\delta^{13} \mathrm{C}$ values of $\underline{\mathrm{G}}$. ruber in the Mediterranean Sea with those measured in the open ocean. Assuming G. ruber has a $\delta^{13} \mathrm{C}$ value of $1.5 \%$ at 8000 years B.P. (S1) and fresh water has a $\delta^{13} \mathrm{C}$ value of $-10 \%$, the contribution of fresh water to the surface waters of the eastern Mediterranean at this time is approximately $6 \%$. In S5, where the $\delta^{13} \mathrm{C}_{\text {Tuber }}$ excursion reaches $-0.09 \%$, the freshwater contribution amounted to $14 \%$. Because $\mathrm{G}$. ruber lives at around $50 \mathrm{~m}$ depth, it does not fully represent the near-surface conditions where phytoplankton grow; these estimates are therefore minima. Such freshwater contributions would lower the $\delta^{13} \mathrm{C}$ of the DIC in the ambient waters to approximately $0.8 \%$ in $\mathrm{S} 1$ and to $-0.1 \%$ in $\mathrm{S} 5$, and this would produce $\delta^{13} C_{\text {organic values of }}-20.7$ to $-21.6 \%$ assuming the modern plankton is $-20 \%$ and the fractionation involved is $-21.5 \%$ (1.5 to $-20 \%$ ). The values in the sapropels reach $-21: 2$ and $-22.8 \%$, respectively.

Hence the lighter $\delta^{13} \mathrm{C}_{\text {organic }}$ values in the sapropels may be partly produced by the effects of fresh water input into the eastern Mediterranean.

The input of fresh water into the eastern Mediterranean would also increase the concentration of dissolved $\mathrm{CO}_{2}$ in surface waters. As proposed by Rau et al. [1989], this would favour a higher degree of discrimination against ${ }^{13} \mathrm{C}$ during photosynthesis, thereby producing ${ }^{13} \mathrm{C}$-depleted organic matter. Such an effect is also consistent with the observations in the Saint Lawrence River [Descolas-Gros and Fontugne, 1990a] showing that the activity of RUBISCO, the enzyme that catalyzes the primary fixation of $\mathrm{CO}_{2}$ during photosynthesis and which discriminates against ${ }^{13} \mathrm{C}$ [Park and Epstein, 1960], is enhanced when salinity is low. Descolas-Gros and Fontugne [1990b] have reviewed the evidence for the occurrence of low $\delta^{13} C_{\text {organic }}$ values and high RUBISCO activity in natural phytoplankton assemblages. Hence these combined effects could be important in producing the light $8^{13} \mathrm{C}_{\text {organic }}$ values within the sapropel horizons in core MD 84641.
The much heavier $\delta^{13} \mathrm{C}$ values in the glacial maximum horizons of core MD 84641 (Figure 3b) also require explanation. Values as heavy as $-17 \%$ are uncommon for open ocean phytoplankton and for marine sediments. As pointed out previously, the reported temperature effect on carbon isotope discrimination [Sackett et al., 1965; Fontugne and Duplessy, 1981; Fontugne, 1983] cannot explain such values because a lower glacial sea surface temperature [Thiede, 1978; Thunell, 1979] would induce lighter rather than heavier $\delta^{13} \mathrm{C}_{\text {organic }}$ values. An alternative metabolic effect which may be involved is the different isotope fractionations induced by different photosynthetic pathways depending on changes in environmental conditions or the assemblages of phytoplankton [Descolas-Gros and Fontugne, 1985; Descolas-Gros and Fontugne, 1990b]. Experimental studies of single species cultures suggest that high activities of RUBISCO are correlated with relatively depleted $\delta^{13} \mathrm{C}$ values, whereas more enriched $\delta^{13} \mathrm{C}$ values were found with high in vitro PEP carboxylase or PEP carboxykinase activities which characterize carbon fixation by $\beta$ carboxylation [Descolas-Gros and Fontugne, 1985]. The association between high RUBISCO activity and light $\delta^{13} \mathrm{C}$ values has also been observed in field phytoplankton assemblages [Descolas-Gros and Fontugne, 1988]. Moreover, Descolas-Gros [1983], Descolas-Gros and de Billy [1983] and DescolasGros and Fontugne [1985] have observed a correlation between the abundance of dinoflagellates and heavy $\delta^{13} \mathrm{C}$ values in natural phytoplankton populations off Portugal. Values as heavy as $-16 \%$ o have been observed in samples where PEP carboxylase activity was also the highest. Dinoflagellate abundances could have been high during the glacial maxima in the eastern Mediterranean in view of the high salinity and low nutrient status of the basin [Thunell and Williams, 1989], so that the high $\delta^{13} C_{\text {organic }}$ values observed in the core would reflect a change in the phytoplankton assemblages present.

Descolas-Gros and Fontugne [1985] found enriched $\delta^{13} \mathrm{C}$ values in laboratory cultures during the end of the exponential growth phase and associated this with metabolic processes linked to the high cell content within the cultures. Degens et al.

[1968] and Fontugne [1983] also found heavy $\delta^{13} \mathrm{C}$ values in the Peru upwelling region and attributed them to the ambient high productivity which could lead to free $\mathrm{CO}_{2}$-limitation as suggested by Deuser [1970] for a diatom bloom in the Black Sea. Descolas-Gros and Fontugne [1990a b] also showed that limitation of free dissolved $\mathrm{CO}_{2}$ with increasing salinity in the Saint Lawrence River estuary induced increasing $\beta$-carboxylase activities in phytoplankton populations leading to the enrichment of ${ }^{13} \mathrm{C}$ in the 
organic tissue. This effect is unlikely to be involved here, however, because the marl oozes have low organic carbon concentrations and, as in the case of the modern eastern Mediterranean, probably represent the deposits of an oligotrophic basin.

The effects of the concentration of dissolved free $\mathrm{CO}_{2}$ on the wide variability of the $\delta^{13} \mathrm{C}_{\text {organic }}$ values of marine plankton have recently been reexamined by Rau et al. [1989], Jasper and Hayes [1990] and Rau et al. [1991]. Accordingly, the marked differences in the carbon isotopic composition of phytoplankton between low and high latitudes [Sackett et al., 1974; Rau et al., 1982; Sackett, 1986a, b] may be linked to the concentration of dissolved $\mathrm{CO}_{2}(\mathrm{aq})$ in the ambient waters, which is largely controlled by sea surface temperature (SST). Thus the greater solubility of $\mathrm{CO}_{2}$ at low SST produces dissolved $\mathrm{CO}_{2}$ levels that are 2.5 times higher for a given $\mathrm{pCO}_{2}$ level at high latitudes (around Antarctica) compared with tropical latitudes [Rau et al., 1989]. Degens et al. [1968] showed that in laboratory experiments the $\delta^{13} \mathrm{C}$ value of phytoplankton is lighter when higher concentrations of $\mathrm{CO}_{2}$ were available in the culture medium, and Degens [1969] suggested that the isotopically light organic matter in ancient sediments is probably caused by a higher abundance of $\mathrm{CO}_{2}$ in the ancient seas. Arthur et al. [1985] and Dean et al. [1986] have likewise suggested that the depleted $\delta{ }^{13}$ Corganic values in Cretaceous strata may be attributed to elevated oceanic, and hence atmospheric, $\mathrm{pCO}_{2}$ levels. McCabe [1985] and Mizutani and Wada [1982] have confirmed the experimental results of Degens et al. [1968], and Degens et al. [1968] and Deuser [1970] have suggested that the heavy $\delta^{13} C_{\text {organic }}$ values sometimes observed in plankton blooms are due to $\mathrm{CO}_{2}$-limitation consequent upon the rapid growth of the phytoplankton.

Jasper and Hayes [1990] have shown that the reconstructed primary $\delta^{13} C_{\text {organic }}$ and the foraminiferal ( $G$, ruber) $\delta^{13} \mathrm{C}$ records in a hemipelagic core from the Gulf of Mexico can be calibrated against the atmospheric $\mathrm{pCO}_{2}$ record obtained from the Vostok ice core [Barnola et al., 1987]. They used a relationship proposed by Popp et al. [1989] between the carbon isotopic fractionation associated with photosynthesis and the concentration of dissolved free $\mathrm{CO}_{2}$ to reconstruct the atmospheric $\mathrm{pCO}_{2}$ record over the last 90,000 years. They produced a $\delta^{13} \mathrm{C}$ record of $\mathrm{C}_{37}$ alkadienones [Jasper and Gagosian, 1989] rather than the total organic carbon to represent the phytoplankton biomass, and by calibrating the fractionation of the carbon isotopes at selected time intervals by reference to surface water dissolved $\mathrm{CO}_{2}$ concentrations derived from the Vostok ice core $\mathrm{CO}_{2}$ record and assuming equilibrium, obtained atmospheric $\mathrm{pCO}_{2}$ values of circa. $180 \mu \mathrm{atm}$ at the last glacial maximum and circa. $272 \mu$ atm in the late Holocene. Use of the $\delta^{13} C_{\text {organic }}$ of the total organic material in the core produced a $\mathrm{pCO}_{2}$ record that was incongruent with that from Vostok because of the influence of terrestrial organic matter in this particular geological setting.

Rau et al. [1991] used the $\delta^{13} C_{\text {organic records of the }}$ total organic fraction of several deep-sea sediment cores [Froelich et al., 1979; Müller et al., 1983; Fontugne and Duplessy, 1986] to extend this approach. They showed that surface water dissolved $\mathrm{CO}_{2}$ concentrations derived from the sediment data, using the empirical relationship between planktonic $\delta^{13} \mathrm{C}$ and surface water dissolved $\mathrm{CO}_{2}$ found earlier by Rau et al. [1989], are consistent with those derived from the atmospheric, and hence oceanic, $\mathrm{pCO}_{2}$ variations provided by the Vostok record if reasonable assumptions are made about sea surface temperature fluctuations over the last glacialinterglacial cycle. Thus changes in the $\delta^{13} C_{\text {organic }}$ of approximately $2 \%$ across the Holocene/glacial transition in cores from the Indian Ocean [Fontugne and Duplessy, 1986] are of the right magnitude to correspond to a $3 \mu \mathrm{M}$ decrease in oceanic $\mathrm{CO}_{2}$ (aq) derived from the ice core record. Such changes in $\delta^{13} C_{\text {organic }}$ are not due to changes in the isotopic composition of the DIC in seawater, since the variations in $\delta^{13} \mathrm{C}$ values of planktonic foraminifera are much smaller $(<0.5 \%)$ between recent and glacial periods.

We have attempted to interpret the the $\delta^{13} C_{\text {organic }}$ record in core MD 84641 (Figure 3b) in a similar way by using the relationship between planktonic $\delta^{13} C_{\text {organic }}$ and measured $\mathrm{CO}_{2}$ (aq) concentrations derived by Rau et al. [1991]. We have made a simple correction to the $\delta^{13} C_{\text {organic }}$ values for the variation in the isotopic composition of the near-surface waters by subtracting the difference between the $\delta^{13} C_{\text {ruber }}$ values (Figure 2b) and the present $\delta^{13} \mathrm{C}$ values $(1.5 \%)$ of the surface water DIC in the eastern Mediterranean [Duplessy, 1972]. Globerigerinoides ruber is known to be a highly variable planktonic species [Emiliani, 1969], and shells of different sizes have significantly different $\delta^{13} \mathrm{C}$ values [Duplessy et al., 1981]. Since we did not separate the foraminiferal samples into different size fractions nor use distinct morphological types in this study, the correction to the $\delta^{13} C_{\text {organic }}$ values is only approximate. However, the corrected values should yield a more accurate estimate of the $\mathrm{CO}_{2}(\mathrm{aq})$ of sea surface water. The resulting dissolved $\mathrm{CO}_{2}$ record (Figure 5a) shows that free dissolved $\mathrm{CO}_{2}$ levels ranged from 4.7 to $11.9 \mu \mathrm{M}$ at the site of core $\mathrm{MD}$ 84641 . The lower values characterize the glacial horizons, especially stages $2-4$ and 10 , and the higher values are confined to the sapropels, whether they occur in interglacial $(S 1, S 3-5$, and S7-10) or 


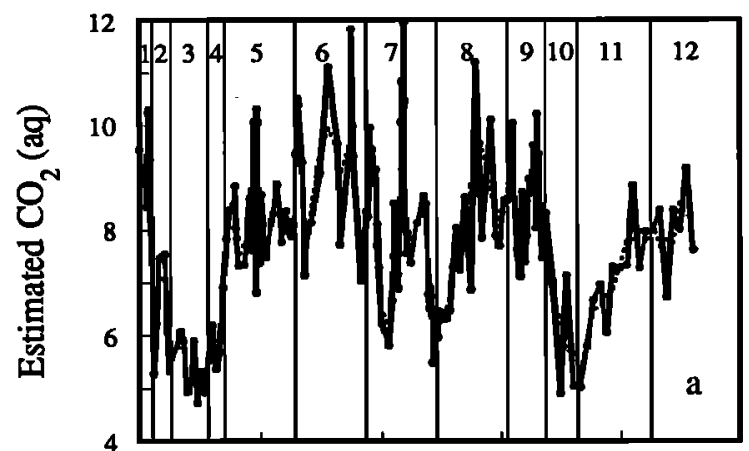

Fig. 5a. Record of surface water dissolved $\mathrm{CO}_{2}$ concentrations estimated from the core $\delta^{13} C_{\text {organic }}$ record using the relationship between $\mathrm{CO}_{2}(\mathrm{aq})$ and planktonic $\delta^{13} \mathrm{C}_{\text {organic }}$ reported by Rau et al. [1991].

glacial (S6) stages. The high values are slightly higher than what one would expect for SST values of around $20^{\circ} \mathrm{C}$ (the average modem value in the eastern Mediterranean) at preindustrial $\mathrm{pCO}_{2}$ levels, whereas the low glacial values are a little lower than those estimated for the last glacial maximum when the average SST was approximately $16^{\circ} \mathrm{C}$. The higher concentrations derived from the sapropel $\delta^{13} C_{\text {organic }}$ values (Figure 3b) may be due, as suggested earlier, to an additional supply of dissolved $\mathrm{CO}_{2}$ from below the mixed layer by, for example, upwelling, which may be have been responsible for the formation of the sapropels [Berger, 1976; Calvert, 1983]. It is noteworthy that the estimated dissolved $\mathrm{CO}_{2}$ values are quite high in Stage 8, where no sapropel occurs, and throughout Stage 9, where a single, thin

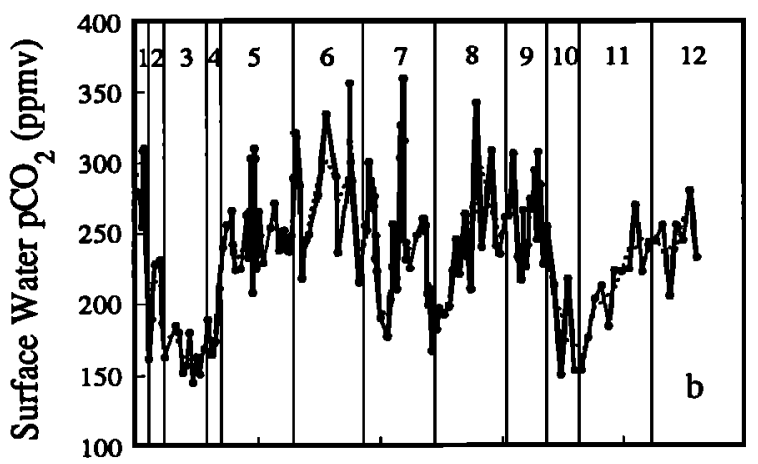

Fig. 5b. Surface water $\mathrm{pCO}_{2}$ record derived from the estimated dissolved $\mathrm{CO}_{2}$ concentrations in Figure 5a using the solubility data of Weiss [1974] and assuming average modern SST = $20^{\circ} \mathrm{C}$ and $\mathrm{S}=38$, average glacial SST $=$ $16^{\circ} \mathrm{C}$ and $\mathrm{S}=40$, and average sapropel SST $=20^{\circ} \mathrm{C}$ and $\mathrm{S}=35$. The dashed line is a three-point moving average.

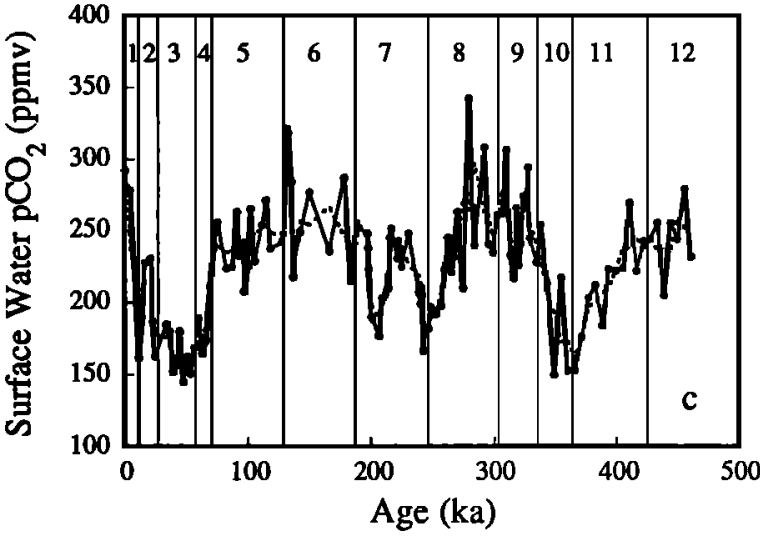

Fig. 5c. Surface water $\mathrm{pCO}_{2}$ record derived from the estimated dissolved $\mathrm{CO}_{2}$ concentrations in the marl oozes only. The dashed line is a threepoint moving average.Stage boundaries are shown at the top of the figures.

sapropel does occur. These results suggest that because of changes in atmospheric $\mathrm{CO}_{2}$ and the supply of additional $\mathrm{CO}_{2}$ by upwelling, the changes in $\delta^{13} \mathrm{C}_{\text {organic }}$ observed in the core could be caused almost entirely by variations in the concentrations of dissolved $\mathrm{CO}_{2}$ in surface waters.

Estimates of the surface water $\mathrm{pCO}_{2}$ levels recorded by the variations in $\delta^{13} C_{\text {organic }}$ have been obtained by taking the estimated values of dissolved $\mathrm{CO}_{2}$ shown in Figure 5a and applying the solubility constants at appropriate temperatures and salinities from Weiss [1974] and assuming (1) oceanatmosphere equilibrium, which is probably reasonable considering the oligotrophic nature of the eastern Mediterranean, (2) that interglacial and sapropel sea surface temperatures were the same as those of today, (3) that glacial SST was $4^{\circ} \mathrm{C}$ lower than that of today [Thiede, 1978; Thunell, 1979] and (4) that the sea surface salinities during glacials, interglacials and sapropel events were 40,38, and 35 , respectively [Thunell and Williams, 1989]. The derived values range from 145 to $359 \mathrm{ppmv}$, with low values in the glacial maxima and high values in interglacials (Figure 5b). The high variability of the estimated $\mathrm{pCO}_{2}$ levels is produced to a some degree by the high values in each of the sapropels, which, as we have suggested, may be due to additional supplies of dissolved $\mathrm{CO}_{2}$ by upwelling, which would cause marked disequilibrium of the dissolved $\mathrm{CO}_{2}$ in the surface waters. A better estimate of surface water $\mathrm{pCO}_{2}$ values that may be compared directly with atmospheric levels may therefore be obtained by omitting the data from the sapropel horizons. The surface $\mathrm{pCO}_{2}$ levels estimated using the data from the marl oozes only are shown in Figure 5c; both the range and the variability of the values are reduced, but the main features of the profile are similar that those shown in Figure 5b. 
Lowest values occur in stages 2-4, 7 and 10-11, whereas the highest values are found in stages 6 and 8-9. On this time scale, the sediment record shows that surface water $\mathrm{pCO}_{2}$ was not necessarily at the lowest level during all glacial maxima.

A direct comparison between the surface water $\mathrm{pCO}_{2}$ values estimated from the $\delta^{13} \mathrm{C}_{\text {organic }}$ values and the Vostok ice core record, using the revised time scale of Shackleton et al. [1990], is shown in Figure 6. The core top values are very similar to the most recent values recorded in the Vostok core [Barnola et al., 1987], whereas the minimum in MD 84641 in stages 2,3 , and 4 is lower $(153 \pm 10$ ppmv) than that in the Vostok record $(203 \pm 11)$. On the other hand, the derived values in stage 5 are similar to those from Vostok, with the values from the two records deviating in stage 6 .

The concordance between surface water $\mathrm{pCO}_{2}$ concentrations derived from sediment records and the atmospheric record from ice cores depends, of course, on the extent of equilibrium between the atmosphere and the sea surface with respect to $\mathrm{CO}_{2}$. Rau et al. [1991] have pointed out that the available data show major departures from equilibrium, so that direct comparisons should be made with caution. One could, in principle, calibrate the $\delta^{13} \mathrm{C}_{\text {organic }}$ record from MD 84641 with the Vostok atmospheric record over the last $140 \mathrm{kyr}$ in a similar manner to that carried out by Jasper and Hayes [1990], but as Rau et al. [1991] have pointed out the adjusted parameter values obtained by these authors (using the

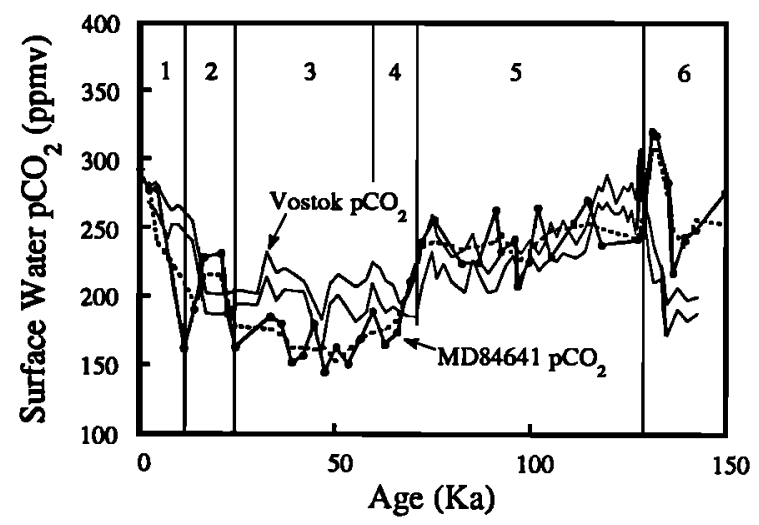

Fig. 6. Comparison between the surface water $\mathrm{pCO}_{2}$ record derived from the $\delta^{13} C_{\text {organic values in }}$ the marl oozes of core MD 84641 and Vostok ice core atmospheric $\mathrm{CO}_{2}$ record from Barnola et al. [1987]. The two solid lines represent the upper and lower error bounds of the Vostok $\mathrm{CO}_{2}$ values. The time scale is that revised by Shackleton et al. [1991]. The dashed line is a three-point moving average through the core data. Stage boundaries are shown at the top of the figure. $\delta^{13} \mathrm{C}$ values of alkenones) are substantially different from those seen in the modern ocean. We have not attempted this, however, because, in addition to the frequent disequilibrium of $\mathrm{CO}_{2}$ at the sea surface, the inherent variability of the $\delta^{13} \mathrm{C}_{\text {ruber values that we }}$ have used to correct the $\delta^{13} C_{\text {organic values from MD }}$ 84641 , alluded to earlier, the need to interpolate at least one of the records used for calibration and because the error in the Vostok record itself would all contribute to an even higher degree of uncertainty in such a calibration. Nevertheless, the reconstruction of atmospheric $\mathrm{pCO}_{2}$ records from sediment cores appears to hold considerable promise. Much longer atmospheric $\mathrm{pCO}_{2}$ records that are linked directly with the marine stratigraphic record [Shackleton, 1990] at minimum cost should be possible using existing piston cores, once the problems of calibration discussed by Rau et al. [1991] are resolved.

\section{SUMMARY AND CONCLUSIONS}

The $\delta^{13} C_{\text {organic }}$ record of core MD 84641 from the eastern Mediterranean shows very large variations between glacial maximum horizons and the sapropels. The depleted values observed in the sapropels are similar to those of modem plankton from the same basin, while the heavy values in the glacials represent much larger ${ }^{13} \mathrm{C}$ enrichments than are observed in any modern marine plankton. Admixtures of significant quantities of terrestrial organic matter in the sediments, temperature effects on isotope fractionation or diagenesis cannot account for these variations. The most likely cause is variations in the isotopic composition and the concentration of dissolved $\mathrm{CO}_{2}$ in the mixed layer of the eastern Mediterranean. Extensive freshwater flooding during the sapropels caused the dissolved $\mathrm{CO}_{2}$ to become significantly lighter, so that the phytoplankton became even more ${ }^{13} \mathrm{C}$ depleted. Increases in total DIC in the surface waters during the deposition of the sapropels due to upwelling also probably led to larger carbon isotope fractionations because of a high concentration of $\mathrm{CO}_{2}(\mathrm{aq})$. In addition, changes in atmospheric $\mathrm{PCO}_{2}$ caused parallel changes in the concentration of dissolved $\mathrm{CO}_{2}$ in the surface waters.

The dissolved $\mathrm{CO}_{2}$ record obtained in this study is similar to that obtained by Rau et al. [1991] from two cores spanning the last $160 \mathrm{kyr}$, one from the northern Atlantic and one from the northern Indian Ocean. In these cores, glacial $\delta^{13} \mathrm{C}_{\text {organic }}$ values are above $-19 \%$, and this produces dissolved $\mathrm{CO}_{2}$ concentrations of approximately $7 \mu \mathrm{M}$. However, other deep-sea cores have $\delta^{13} C_{\text {organic }}$ records that show either no change between the Holocene and the last glacial maximum [Pedersen et al.,1991] or lighter values during glacial maxima [Fontugne, 
1983], implying that the explanation given here and by Rau et al. [1991] does not apply globally. This conundrum can be explained, however, by the differences in the oceanographic settings of the cores from which these records were obtained. That is, eutrophic regions, where upwelling supplies both nutrients and dissolved $\mathrm{CO}_{2}$ to the mixed layer, may have had high $\mathrm{CO}_{2}$ concentrations during the last glacial maximum even though atmospheric $\mathrm{CO}_{2}$ levels were lower [Pedersen et al., 1991]. This would have been even more true if such regions had enhanced upwelling because of higher wind speeds compared to modern conditions, as suggested for the equatorial Pacific by Pedersen [1983]. On the other hand, the oligotrophic regions of the ocean, especially the subtropical gyres and the Mediterranean, may not have changed their states so that nutrient limitation was accompanied by lower dissolved molecular $\mathrm{CO}_{2}$ concentrations because of lower atmospheric $\mathrm{CO}_{2}$ levels. Thus, although longer atmospheric $\mathrm{CO}_{2}$ records could potentially be obtained from deep-sea piston cores than can presently be obtained from ice cores, a judicious selection of the locations of the cores with respect to particular oceanographic settings will be required.

Acknowledgments. The collection of the cores was made possible by Territoire des Terres Australes et Antarctiques Françaises (Noé-Cruise of the R/V Marion-Dufresne). We thank Mark Noyon and Maureen Soon for assistance in the laboratory and $\mathrm{B}$. Nielsen for carrying out the $\delta^{13} \mathrm{C}_{\text {organic }}$ measurements at the University of British Columbia, L.D. Labeyrie for providing facilities for $\delta^{180}$ analysis and $\mathrm{M}$. Paterne who provided samples and the stratigraphy of core DED 8708. We thank T. F. Pedersen and J. C. Duplessy for enlightening discussion of some of the interpretations offered in this paper, and J. P. Jasper and G. H. Rau for very helpful and constructive formal reviews. S.E.C. acknowledges support from Centre National de la Recherche Scientifique(CNRS, France),Commisariat à l'Energie Atomique (CEA, France) and the Natural Sciences and Engineering Research Council of Canada during the completion of this study. Centre des Faibles Radioactivités (CFR) Contribution 1212.

\section{REFERENCES}

Arthur, M. A., W. E. Dean, and G. E. Claypool, Anomalous C-13 enrichment in modern marine organic carbon, Nature, 315, 216-218, 1985.

Barnola, J. M., D. Raynaud, Y. S. Korotkevich, and C. Lorius, Vostok ice core provides 160000 year record of atmospheric $\mathrm{CO}_{2}$, Nature, 329,408 414, 1987.

Benner, R., M. L. Fogel, E. K. Sprague, and R. E. Hodson, Depletion of $13 \mathrm{C}$ in lignin and its implications for stable carbon isotope studies, Nature, 329, 708-710, 1987.

Berger, W. H., Biogenous deep-sea sediments: production, peservation and interpretation, in Chemical Oceanography, edited by J. P. Riley and R. Chester, pp. 265-388, Academic, San Diego, Calif., 1976.

Calder, J. A., and P. L. Parker, Stable carbon isotope ratio as indices of petrochemical pollution of aquatic systems, Environ. Sci. Technol., 2, 535-539, 1968.

Calvert, S. E., Geochemistry of Pleistocene sapropels and associated sediments from the Eastern Mediterranean, Oceanol. Acta, $\underline{6}, 255$ 267, 1983.

Calvert, S. E., Oceanographic controls on the accumulation of organic matter in marine sediments, in Marine Petroleum Source Rocks edited by J. Brooks and A. J. Fleet, pp. 137-151, Blackwell Scientific, Boston, Mass., 1987.

Calvert, S. E., and M. R. Fontugne, Stable carbon isotopic evidence for the marine origin of the organic matter in the Holocene Black Sea sapropel, Chem. Geol., 66, 315-322, 1987.

Cheddadi, R., Paléoclimats au nord de la Méditerranée orientale depuis 250,000 ans . Analyse Pollinique et stratigraphie isotopique de quatre carottes marines, Doctorate, 118pp, Univ. of Montpellier, Montpellier, France, 1988.

Cita, M. B., and D. Grignani, Nature and origin of Late Neogene Mediterranean sapropels, in The Nature and Origin of Cretaceous Carbon-rich Facies, edited by S. O. Schlanger and M. B. Cita, pp. 165-196, Academic, San Diego, Calif., 1982.

Cita, M. B., C. Vergnaud-Grazzini, C. Robert, H. Chamley, N. Ciaranfi, and S. d'Onofrio, Paleoclimatic record of a long deep-sea core from the eastern Mediterranean, Quat. Res., $\underline{8}, 205-235$, 1977.

Dean, W. E., M. A. Arthur, and G. E. Claypool, Depletion of $\mathrm{C}-13$ in cretaceous marine organic matter: source, diagenetic, or environmental signal?, Mar. Geol, 70, 119-157, 1986.

Degens, E. T., Biogeochemistry of stable carbon isotopes, in Organic Geochemistry, edited by G. Eglinton and M. T. J. Murphy, pp. 304-329, Elsevier, New York, 1969.

Degens, E. T., M. Behrendt, B. Gotthard, and E. Reppmann, Metabolic fractionation of carbon isotopes in marine plankton. II. Data on samples collected off the coast of Peru and Ecuador, Deep Sea Res., 15, 11-20, 1968.

Deines, P., The isotopic composition of reduced carbon, in Handbook of Environmental Isotope Geochemistry, edited by P. Fritz and J. C. Fontes, pp. 329-406, Elsevier, Amsterdam, 1980.

Deroo, G., J. P. Herbin, and J. Roucache, Organic geochemistry of some Neogene cores from Sites 374, 375, 377 and 378: Leg 42A, eastern 
Mediterranean Sea, Initial Rep. Deep Sea Drill. Proj., 42A, 465-472, 1978.

Descolas-Gros, C., Les voies d'incorporation photosynthetique du carbone du phytoplancton. Signification ecologique de l'activite des carboxylases en milieu marin. Comparasion avec le rapport $13 \mathrm{C} / 12 \mathrm{C}$ du carbone organique $\mathrm{du}$ phytoplancton, Doctorate, 117 pp., Univ.of Paris, 1983.

Descolas-Gros, C., and G. de Billy, Dosage de l'activite de quelques carboxylases et mesure du rapport isotopique $13 \mathrm{C} / 12 \mathrm{C}$ du phytoplancton, in Resultats des Campagnes a la Mer CNEXO, edited by G. Mediprod, pp. 85-88, Centre National pour l'Exploitation des Océans (CNEXO), Brest, 1983.

Descolas-Gros, C., and M. R. Fontugne, Carbon fixation in marine phtoplankton: carboxylase activities and stable carbon isotope ratios: physiological and paleoclimatological aspects. Mar. Biol., 87, 1-6, 1985.

Descolas-Gros, C., and M. R. Fontugne, Carboxylase activities and carbon isotope ratios of Mediterranean phytoplankton, in Oceanographie Pelagique Mediterranee. edited by H. J. Minas and P. Nival, Oceanol. Acta Spec. Issue, 245-250, 1988.

Descolas-Gros, C., and M. R. Fontugne, Dynamics of carbon assimilation by the St. Lawrence Estuary phytoplankton at the end of summer, Hydrobiologia, 207, 227-232, 1990a.

Descolas-Gros, C., and M. R. Fontugne, Stable carbon isotope fractionation by marine phytoplankton during photosynthesis, Plant Cell Environ., 13, 207-218, $1990 \mathrm{~b}$.

Deuser, W. G., Isotopic evidence for diminishing supply of available carbon during diatom bloom in the Black Sea, Nature, 225, 1069, 1970.

Duplessy, J.-C., La géochimie des isotopes stables du carbone dans la mer, Doctorate, 196 pp., Univ. of Paris, 1972.

Duplessy, J.-C., A. W. H. Bé, and P. L. Blanc, Oxygen and carbon isotopic composition and biogeographic distribution of planktonic foraminifera in the Indian Ocean, Palaeogeogr. Palaeoclimatol. Palaeoecol, 33, 9-46, 1981.

Emiliani, C., Pleistocene temperatures, J. Geol., 63, 538-578, 1955.

Emiliani, C., A new micropaleontology, Micropaleontology, 15, 265-300, 1969.

Fontugne, M. R., Les isotopes stables du carbone organique dans l'océan. Application à la palaeoclimatologie, Doctorate, 224 pp., Univ. of Paris, 1983.

Fontugne, M. R., and J.-C. Duplessy, Carbon isotope ratio of marine plankton related to water masses, Earth Planet. Sci. Lett., 41, 365-371, 1978.

Fontugne, M. R., and J.-C. Duplessy, Organic carbon isotopic fractionation by marine plankton in the temperature range -1 to $31^{\circ} \mathrm{C}$, Oceanol. Acta,, 85-90, 1981.
Fontugne, M. R., and J.-C. Duplessy, Variations of the monsoon regime during the upper Quaternary: evidence from carbon isotopic record of organic matter in north Indian Ocean sediment cores, Palaeogeogr. Palaeoclimatol. Palaeoecol,, 56, 6988, 1986.

Fontugne, M. R., and J. M. Jouanneau, Modulation of the particulate organic carbon flux to the ocean by a macrotidal estuary: evidence from measurements of carbon isotopes in organic matter from the Gironde system, Estuarine Coastal Shelf Res., 24, 377-387, 1987.

Fontugne, M. R., M. Arnold, L. D. Labeyrie, and J.-C. Duplessy, Initiation de la stratification de la Mediterranée orientale et débit du Nil à l'Holocène, in Past and Future Evolution of Deserts, Actes Colloque Prog.Int. Corr.Geol.(IGPC) 252, Jerba, Tunisia, in press, $1989 \mathrm{a}$.

Fontugne, M. R., M. Paterne, S. E. Calvert, A. Murat, F. Guichard, and M. Amold, Adriatic deep water formation during the holocene: implication for the reoxygenation of the deep eastern Mediterranean Sea, Paleoceanography, 4, 199206, 1989b.

Froelich, P. N., G. P. Klinkhammer, M. L. Bender, N. A. Luedtke, G. R. Heath, D. Cullen, P. Dauphin, D. Hammond, B. Hartman, and V. Maynard, Early oxidation of organic matter in pelagic sediments of the eastern equatorial Atlantic: suboxic diagenesis, Geochim. Cosmochim. Acta, 43, 1075-1090, 1979.

Gearing, P., F. E. Plucker, and P. L. Parker, Organic carbon stable isotope ratios of continental margin sediments, Mar. Chem., 5, 251-266, 1977. Hayes, J. M., B. N. Popp, R. Takigiku, and M. W. Johnson, An isotopic study of biogeochemical relationships between carbonates and organic carbon in the Greenhorn Formation, Geochim. Cosmochim. Acta, 53, 2961-2972, 1989.

Hedges, J. I., W. A. Clark, P. D. Quay, J. E. Richey, A. H. Devol, and U. d. M. Santos, Compositions and fluxes of particulate material in the Amazon River, Limnol. Oceanogr., 31, 717738, 1986.

Jasper, J. P., and R. B. Gagosian, Alkenone molecular stratigraphy in an oceanic environment affected by glacial freshwater events,

Paleoceanography, 4, 603-614, 1989.

Jasper, J. P., and R. B. Gagosian, The sources and deposition of organic matter in the Late Quaternary Pigmy Basin, Gulf of Mexico, Geochim. Cosmochim. Acta, 54, 1117-1132, 1990.

Jasper, J. P., and J. M. Hayes, A carbon-isotopic record of $\mathrm{CO}_{2}$ levels during the Late Quaternary, Nature, 347, 462-464 1990.

Jenkins, J. A., and D. F. Williams, Nile water as a cause of eastern Mediterranean sapropel formation: evidence for and against, Mar. Micropaleontol., 9, 521-534, 1984.

Joyce, J. E., M. C. Kennicutt II, and J. M. Brooks, 
Late Quaternary depositional history of the deep western Gulf of Mexico: geochemical and sedimentologic evidence, Mar. Geol., 69, 55-68, 1985.

Kidd, R. B., M. B. Cita, and W. B. F. Ryan, Stratigraphy of eastern Mediterranean sapropel sequences recovered during Leg $42 \mathrm{~A}$ and their paleoenvironmental significance, Initial Rep. Deep

Sea Drill. Proj., 42A , 421-443, 1978.

Kullenberg, B., On the salinity of the water contained in marine sediments, Goteborgs K. Vetensk. Vitterhets-Samh. Handl..Ser. B, 6, 3-37, 1952.

Martinson, D. G., N. G. Pisias, J. D. hays, J. Imbrie, T. C. Moore Jr, and N. J. Shackleton, Age Dating and the Orbital theory of the Ice Ages: Development of a High-resolution 0 to 300000 year chronostratigraphy, Ouat. Res., 27, 1-29, 1987.

McArthur, J. M., R. V. Tyson, J. Thomson, and D. Mattey, Early diagenesis of organic matter: alteration of the carbon isotopic composition, $\underline{\text { Mar. }}$ Geol., in press, 1991.

McCabe, B., The dynamics of ${ }^{13} \mathrm{C}$ in several New Zealand lakes, Doctorate, 277 pp., Waikato Univ., Waikato, N.Z., 1985.

McCoy, F. W., Late Quaternary sedimentation in the eastern Mediterranean Sea, Doctorate, Harvard Univ., 132 pp., Cambridge, Mass., 1974.

Mizutani, H., and E. Wada, Effect of high atmospheric $\mathrm{CO}_{2}$ concentration on $\delta^{13} \mathrm{C}$ of algae, Origins Life, 12, 377-390, 1982.

Müller, P. J., C/N ratios in Pacific deep-sea sediments; Effect of inorganic ammonium and organic nitrogen compounds sorbed by clays, Geochim. Cosmochim. Acta, 41, 765-776, 1977.

Müller, P. J., H. Erlenkeuser, and R. von Grafenstein, Glacial-interglacial cycles in oceanic productivity inferred from organic carbon contents in eastern north Atlantic sediment cores, in Coastal Upwelling, Part B, edited by J. Thiede and E. Suess, pp. 365-398, Plenum Press, New York, 1983.

Neuman, J. W., P. L. Parker, and E. W. Behrens, Organic carbon isotope ratios in Quaternary cores from the Gulf of Mexico, Geochim. Cosmochim. Acta, 37, 225-238, 1973.

Olausson, E., Studies of deep-sea cores, Rep. Swed. Deep Sea Exped., 8, 335-391, 1961.

Park, R., and S. Epstein, Carbon isotope fractionation during photosynthesis, Geochim. Cosmochim. Acta, 21, 110-126, 1960.

Parker, P. L., The biogeochemistry of the stable carbon isotopes in a marine bay, Geochim. Cosmochim. Acta, 28, 1155-1164, 1964.

Pedersen, T. F., Increased productivity in the eastern equatorial Pacific during the last glacial maximum (19 000 to 14000 yr B.P.), Geology, $\underline{11}, 16-19,1983$.
Pedersen, T. F., B. Nielsen, and M. Pickering, Late Quatemary cyclicity and timing of productivity cycles in the Panama Basin: Implications for atmospheric $\mathrm{CO}_{2}$, Paleoceanography, in press, 1991.

Popp, B. N., R. Takigiku, J. M. Hayes, J. W. Louda, and E. W. Baker, The post-Paleozoic chronology and mechanism of ${ }^{13} \mathrm{C}$ depletion in primary marine organic matter, Am. J. Sci., 289, 436-454, 1989.

Rasmussen, K. A., R. I. Haddad, and A. C. Neumann, Stable-isotope record of organic carbon from an evolving carbonate banktop, Bight of Abaco, Bahamas, Geology, 18, 790-794, 1990.

Rau, G. H., R. E. Sweeney, and I. R. Kaplan, Plankton $13 \mathrm{C} / 12 \mathrm{C}$ ratio changes with latitude: differences betyween northern and southern ocean, Deep Sea Res., 29, 1035-1039, 1982.

Rau, G. H., T. Takahashi, and D. J. Des Marais, Latitudinal variations in plankton $\delta^{13} \mathrm{C}$ : implications for $\mathrm{CO}_{2}$ and productivity in past oceans, Nature, $341,516-518,1989$.

Rau, G. H., P. N. Froelich, T. Takahashi, and D. J. Des Marais, Does sedimentary organic $\delta^{13} \mathrm{C}$ record variations in Quaternary ocean $\left[\mathrm{CO}_{2}(\mathrm{aq})\right]$ ?, Paleoceanography, 6, 335-347, 1991.

Redfield, A. C., B. H. Ketchum, and F. A. Richards, The influence of organisms on the composition of sea water, in The Sea, edited by $M$. N. Hill, pp. 26-77, John Wiley, New York, 1963.

Rogers, M. A., and C. B. Koons, Organic carbon $\delta^{13} \mathrm{C}$ values from Quaternary marine sequences in the Gulf of Mexico: A reflection of paleotemperature changes, Trans. Gulf Coast Assoc. Geol. Soc., 19, 529-534, 1969.

Rossignol-Strick, M., African monsoons, an immediate climate response to orbital insolation, Nature, 304, 46-49, 1983.

Rossignol-Strick, M., Mediterranean Quaternary sapropels, an immediate response of the African Monsoon to variation of insolation, Palaeogeogr. Palaeoclimatol. Palaeoecol., 49, 237-263, 1985.

Rossignol-Strick, M., W. Nesteroff, P. Olive, and C. Vergnaud-Grazzini, After the deluge: Mediterranean stagnation and sapropel formation, Nature, 295, 105-110, 1982.

Ryan, W. B. F., Stratigraphy of Late Quaternary sediments in the eastern Mediterranean, in The Mediterranean Sea, edited by D. J. Stanley, pp. 149-169, Dowden, Hutchinson and Ross, Stroudsbury, Pa., 1972.

Ryan, W. B. F., and M. B. Cita, Ignorance concerning episodes of ocean-wide stagnation, Mar. Geol., 23, 193-215, 1977.

Sackett, W. M., The depositional history and isotopic organic carbon composition of marine sediments, Mar. Geol., 2, 173-185, 1964. 
Sackett, W. M., $\delta^{13} \mathrm{C}$ signatures of organic carbon in southern high latitude deep-sea sediments: paleotemperature implications, $\underline{\text { Org. Geochem., }} \underline{9}$, 63-68, 1986a.

Sackett, W. M., Organic carbon in sediments underlying Ross Ice Shelf, Org. Geochem., 2 , 135-137, 1986b.

Sackett, W. M., and J. G. Rankin, Paleotemperatures for the Gulf of Mexico, $\mathrm{J}$. Geophys. Res., 75, 4557-4560, 1970.

Sackett, W. M., and R. R. Thompson, Isotopic organic carbon composition of recent continental derived clastic sediments of eastern gulf coast, Gulf of Mexico, Am. Assoc. Petrol. Geol, Bull., 47, 525, 1963.

Sackett, W. M., W. R. Ekelmann, M. L. Bender, and $\mathrm{A} . \mathrm{W} . \mathrm{H}$. Be, Temperature dependence of carbon isotope composition in marine plankton and sediments, Science, 148, 235-237, 1965.

Sackett, W. M., B. J. Eadie, and M. E. Exner, Stable isotope composition of organic carbon in recent Antarctic sediments, in Advances in Organic Geochemistry, edited by B. Tissot and F. Biener, pp. 661-671, Pergamon Press, New York, 1974.

Saliot, A., J. Tronczynski, P. Scribe, and R. Letolle, The application of isotopic and biogeochemical markers to the study of the biochemistry of organic matter in a macrotidal estuary, the Loire, France, Estuarine Coastal Shelf Sci., 27, 645-669, 1988.

Salomons, W., and W. G. Mook, Field observations of the isotopic composition of particulate organic carbon in the southem North Sea and adjacent estuaries, Mar. Geol., 41, M11M20, 1981.

Sarnthein, M., K. Winn, J.-C. Duplessy, and M. R. Fontugne, Global variations of surface ocean productivity in low and high latitudes: Influence on $\mathrm{CO} 2$ reservoirs of the deep ocean and atmosphere during the last 21,000 years, Paleoceanography, 3, 361-399, 1988.

Shackleton, N. J., Estimating atmospheric $\mathrm{CO} 2$, Nature, 347, 427-428, 1990.

Shackleton, N. J., J. Le, A. Mix, and M. A. Hall., Carbon isotope records from Pacific surface waters and atmospheric carbon dioxide, Quat. Sci. Rev, in press, 1991.

Shaw, H. F., and G. Evans, The nature, distribution and origin of a sapropelic layer in sediments of the Cilicia Basin, northeastern Mediterranean, Mar. Geol., 61, 1-12, 1984.

Shultz, D. J., and J. A. Calder, Organic carbon $13 \mathrm{C} / 12 \mathrm{C}$ variations in an estuarine environment, Geochim. Cosmochim. Acta, 40, 381-385, 1976.

Sigl, W., H. Chamley, F. Fabricius, G. G. d'Argoud, and J. Muller, Sedimentology and environmental conditions of sapropels, Initial Reports of the Deep-Sea Drilling Project, 42A, 445-465, 1978.

Smith, D. J., G. Eglinton, and R. J. Morris, The lipid geochemistry of a recent sapropel and associated sediments from the Hellenic Outer Ridge, eastem Mediterranean Sea, Philos. Trans. R. Soc. London, ser.A.319, 375-415, 1986.

Spiker, E. C., and P. G. Hatcher, Carbon isotope fractionation of sapropelic organic matter during diagenesis, Org. Geochem., 5, 283-290, 1984.

Stanley, D. J., and A. Maldonado, Nile Cone: Late Quaternary stratigraphy and sediment dispersal, Nature, 266, 129-135, 1977.

Stevenson, F. J., and C. N. Cheng, Organic geochemistry of the Argentine Basin sediments: carbon-nitrogen relationships and Quaternary correlations, Geochim. Cosmochim. Acta, $\underline{36}$, 653-671, 1972.

Suess, E., and P. J. Müller, Productivity, sedimentation rate and sedimentary organic matter in the oceans II - Elemental fractionation, in Biogéochimie de la Matière Organique à l'Interface Eau-Sédiment Marin, edited by R. Daumas, Coll. Int. C.N.R.S., 293, 18-26, 1980.

Sutherland, H., S. E. Calvert, and R. J. Morris, Geochemical studies of the recent sapropel and associated sediment from the Hellenic Outer Ridge, Eastern Mediterranean Sea. I. Mineralogy and

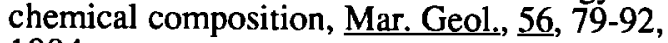
1984.

Tan, F. C., and P. M. Strain, Carbon isotope ratios of particulate organic matter in the Gulf of St. Lawrence, J. Fish. Res. Board. Can., 36, 678$682,1979 \mathrm{a}$.

Tan, F. C., and P. M. Strain, Organic carbon ratios in recent sediments in the St. Lawrence Estuary and the Gulf of St. Lawrence, Estuarine. Coastal Mar. Sci., $\underline{8}, 213-225,1979 \mathrm{~b}$.

Tan, F. C., and P. M. Strain, Sources, sinks and distribution of organic carbon in the St. Lawrence estuary, Canada, Geochim. Cosmochim. Acta, 47, 125-132, 1983.

Ten Haven, H. L., M. Baas, M. Kroot, J. W. de Leeuw, P. A. Schenk, and J. Ebbing, Late Quaternary Mediterranean sapropels. III: Assessment of source of input and paleotemperature as derived from biological markers, Geochim. Cosmochim. Acta, 51, 803$810,1987$.

Thiede, J., A glacial Mediteranean, Nature, 276, 680-683, 1978.

Thunell, R. C., A glacial reconstruction of the eastern Mediterranean Sea, 18,000 years B.P., Ouat. Res., 11, 353-372, 1979.

Thunell, R. C., and D. F. Williams, Paleoceanographic events associated with Termination II in the eastern Mediterranean, Oceanol. Acta, 5, 229-233, 1982.

Thunell, R. C., and D. F. Williams, GlacialHolocene salinity changes in the Mediterranean Sea: hydrographic and depositional effects, Nature, 338, 493-496, 1989.

Thunell, R. C., D. F. Williams, and J. P. Kennett, 
Late Quaternary paleoclimatology, stratigraphy and sapropel history in the eastern Mediterranean, Mar. Micropaleontol., 2, 371-388, 1977.

Thunell, R. C., D. F. Williams, and M. B. Cita, Glacial anoxia in the eastern Mediterranean, $\mathbf{J}$. Foraminiferal Res., 13, 283-290, 1983.

Tucholka, P., M. R. Fontugne, F. Guichard, and M. Paterne, The Blake magnetic polarity episode in cores from the Mediterranean Sea, Earth Planet. $\underline{\text { Sci }}$

Lett., 86, 320-326, 1987.

Vergnaud-Grazzini, C., W. B. F. Ryan, and M. B. Cita, Stable isotope fractionation, climate change and episodic stagnation in the eastern Mediterranean during the Late Quaternary, Mar. Micropaleontol., 2, 353-370, 1977.

Weiss, R. F., Carbon dioxide in seawater: The solubility of a non-ideal gas, Mar. Chem., 2, 203215, 1974.

Williams, D. F., and R. C. Thunell, Faunal and oxygen isotopic evidence for surface water salinity changes during sapropel formation in the eastern Mediterranean, Sediment. Geol., 23, 81-93, 1979. Williams, D. F., R. C. Thunell, and J. P. Kennett, Periodic freshwater flooding and stagnation of the eastern Mediterranean Sea during the Late Quaternary, Science, 201, 252-254, 1978.

S.E. Calvert, Department of Oceanography, University of British Columbia, Vancouver, B.C.,Canada V6T 1 W5

M.R. Fontugne, Centre des Faibles Radioactivités, Laboratoire mixte CNRS-CEA, Avenue de la Terrasse, 91198 Gif sur Yvette Cedex, France

(Received June 14, 1991;

revised October 14, 1991;

accepted October 16, 1991.) 